\title{
Preparation, Characterization of Graphitic Carbon Nitride Photo-Catalytic Nanocomposites and Their Application in Wastewater Remediation: A Review
}

\author{
Caifang $\mathrm{Li}^{1,+}$, Xianliang Wu ${ }^{2,+}$, Junyue Shan ${ }^{1}$, Jing Liu ${ }^{3}$ and Xianfei Huang ${ }^{1, *(D)}$ \\ 1 Guizhou Provincial Key Laboratory for Information Systems of Mountainous Areas and Protection of \\ Ecological Environment, Guizhou Normal University, Guiyang 550001, China;

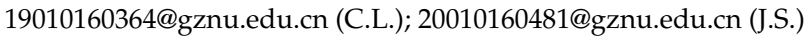 \\ 2 Guizhou Institute of Biology, Guiyang 550009, China; 16010160437@gznu.edu.cn \\ 3 College of Life Sciences, Guizhou Normal University, Guiyang 550001, China; 19010100278@gznu.edu.cn \\ * Correspondence: hxfswjs@gznu.edu.cn; Tel.: +86-136-3911-0513 \\ + These authors contributed equally to this work.
}

\section{check for}

updates

Citation: Li, C.; Wu, X.; Shan, J.; Liu, J.; Huang, X. Preparation, Characterization of Graphitic Carbon Nitride Photo-Catalytic

Nanocomposites and Their Application in Wastewater Remediation: A Review. Crystals 2021 11, 723. https://doi.org/10.3390/ cryst 11070723

Academic Editors: Guorui Wang, Changhong Cao and Mahdi Hamidi

Received: 24 May 2021

Accepted: 18 June 2021

Published: 23 June 2021

Publisher's Note: MDPI stays neutral with regard to jurisdictional claims in published maps and institutional affiliations.

Copyright: (c) 2021 by the authors. Licensee MDPI, Basel, Switzerland. This article is an open access article distributed under the terms and conditions of the Creative Commons Attribution (CC BY) license (https:// creativecommons.org/licenses/by/ $4.0 /)$
Abstract: Energy crisis and environmental pollution are the major problems of human survival and development. Photocatalytic technology can effectively use solar energy and is prospective to solve the above-mentioned problems. Carbon nitride is a two-dimensional polymer material with a graphite-like structure. It has good physical and chemical stabilities, unique chemical and electronic energy band structures, and is widely used in the field of photocatalysis. Graphitic carbon nitride has a conjugated large $\pi$ bond structure, which is easier to be modified with other compounds. thereby the surface area and visible light absorption range of carbon nitride-based photocatalytic composites can be insignificantly increased, and interface electron transmission and corresponding photogenerated carriers separation of streams are simultaneously promoted. Therefore, the present study systematically introduced the basic catalytic principles, preparation and modification methods, characterization and calculation simulation of carbon nitride-based photocatalytic composite materials, and their application in wastewater treatment. We also summarized their application in wastewater treatment with the aid of artificial intelligence tools. This review summarized the frontier technology and future development prospects of graphite phase carbon nitride photocatalytic composites, which provide a theoretical reference for wastewater purification.

Keywords: graphite carbon nitride nanocomposites; photocatalysts; wastewater; computational simulation; artificial intelligence

\section{Introduction}

With the development of industry and society, water pollution is becoming increasingly serious, which is a worldwide problem of environmental governance [1-3]. The sources of water pollution are mainly industrial wastewater, agricultural and domestic sewage [4,5]. At present, several researchers on water environmental pollution mainly focus on the refractory organic pollutants, which is probably due to a longer retention period in the environment and accumulate in the biological chain in the process of continuous material exchange in nature [6,7]. With the composition of organic pollutants becoming sharply complex, the number and types of organic pollutants are increasing rapidly. In addition, their toxicities are also significantly enhanced, causing more serious harm to the water environment [8,9]. Therefore, for the sake of people's health, economic and social sustainable development, it is urgent to prevent water pollution, protect and improve the environment and ensure the safety of drinking water.

Currently, wastewater remediation is mainly divided into physical, chemical, physicalchemical, and biological treatment methods [10,11]. However, several highly toxic organic compounds are difficult to be effectively removed by traditional treatment way due to 
their complex chemical structure [12-16]. Therefore, it is urgent to develop effective and emerging technologies used to treat organic wastewater. Photocatalysis is a branch of heterogeneous catalysis, which can use light energy for material conversion. Further, photocatalytic oxidation technology is extensively used in the field of environment and energy, especially for wastewater treatment (i.e., dyes, antibiotics, pesticides), gas purification (NOx, SOx, VOCs, etc.), photolysis of water to produce hydrogen, reduction of $\mathrm{CO}_{2}$ [17-20]. Photocatalytic materials mainly include metal oxides (e.g., $\mathrm{TiO}_{2}, \mathrm{Fe}_{2} \mathrm{O}_{3}, \mathrm{ZnO}, \mathrm{Bi}_{2} \mathrm{O}_{3}$ and $\left.\mathrm{Cu}_{2} \mathrm{O}\right)$, metal sulfides (CDs and $\mathrm{MoS}_{2}$ ), Bi-based photocatalysts, graphite carbon nitride $\left(\mathrm{g}-\mathrm{C}_{3} \mathrm{~N}_{4}\right)$, elemental semiconductor photocatalysts and monatomic photocatalysts [21-26]. Especially, carbon nitride is a new covalent compound, whose hardness is comparable to that of diamond and has not been found in nature [27]. It has a variety of allotypes, including $\alpha-C_{3} N_{4}, \beta-C_{3} N_{4}$, cubic phase $C_{3} N_{4}$, quasi cubic phase $C_{3} N_{4}$ and graphite phase $C_{3} N_{4}$. Among them, the structure of graphite phase $\mathrm{C}_{3} \mathrm{~N}_{4}$ with a similar graphite layer structure is the most stable $[28,29]$. Graphitic carbon nitride is metal-free, non-toxic, and side effects, has good biocompatibility, abundant in the earth, and readily synthesized [30]. It has excellent chemical and thermal stability, with a bandgap of about $2.7 \mathrm{eV}$, and fine optical and electrical properties [31-34]. Its suitable bandgap can respond to visible light, which has important values in the fields of photocatalytic hydrogen decomposition, artificial photosynthesis, organic pollutant degradation and $\mathrm{CO}_{2}$ reduction [35-38].

With the development of computer technology and the rise of artificial intelligence, all walks of life have the trend of automation and intelligence [39-42]. Currently, the wastewater treatment management and control system overly reliant on the experience of knowledge workers to make decisions, and there are many process data. Therefore, it is difficult to be used for process management and control. The application of new generation artificial intelligence technology in wastewater treatment can achieve multiobjective optimal control $[43,44]$. Up to now, the photocatalytic mechanism, preparation methods and functionalization of $\mathrm{g}-\mathrm{C}_{3} \mathrm{~N}_{4}$ and its composites have been widely reported, whereas there are few reports on advanced characterization techniques, computational simulation (i.e., density functional theory, molecular simulation and Monte Carlo) and artificial intelligence tools. Overall, the present study will systematically review the latest progress of $\mathrm{g}-\mathrm{C}_{3} \mathrm{~N}_{4}$ photocatalyst, and the basic mechanism and internal key steps of $\mathrm{g}-\mathrm{C}_{3} \mathrm{~N}_{4}$ photocatalyst degradation of pollutants. Meanwhile, the present study will exhibit the preparation methods and modification techniques of $g-\mathrm{C}_{3} \mathrm{~N}_{4}$ composites are discussed, and its new characterization techniques and computational simulation. In addition, We will elaborate the application of photocatalyst in wastewater treatment and artificial intelligence tools in the pollutant degradation process. Finally, we will summary the problems and challenges faced by composite materials in the field of photocatalysis and prospect its future development trend to promote the further development of their application in photocatalysis.

\section{Basic Principles of Graphitic Carbon Nitride Photocatalytic Nanocomposites for Pollutant Degradation}

The band theory can clearly explain the photocatalytic mechanism of $\mathrm{g}-\mathrm{C}_{3} \mathrm{~N}_{4}$ photocatalyst. According to the solid band theory, the band structure of semiconductors is discontinuous. There is a bandgap between the valence band (VB) filled with electrons and the empty or dissatisfied conduction band (CB). The size of bandgap determines the redox ability and photo responsiveness of semiconductor photocatalysts. The specific photocatalytic reaction path of $\mathrm{g}-\mathrm{C}_{3} \mathrm{~N}_{4}$ is shown in Figure 1. 


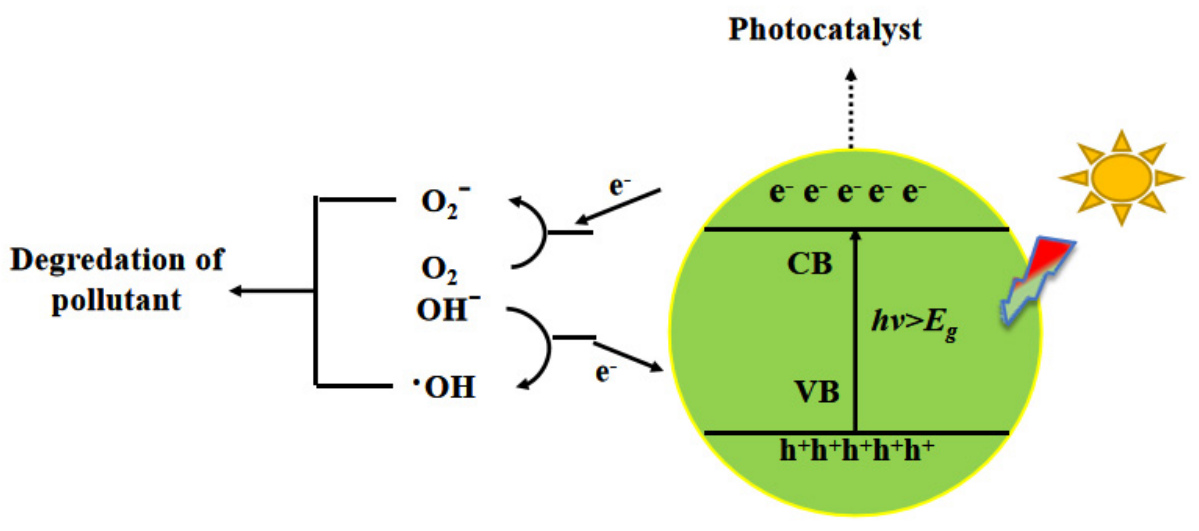

Figure 1. Schematic diagram of $\mathrm{g}-\mathrm{C}_{3} \mathrm{~N}_{4}$ photocatalysis.

As shown in Figure 1, the photocatalytic reaction occurs when g- $\mathrm{C}_{3} \mathrm{~N}_{4}$ absorbs photons not less than the bandgap energy. The whole catalytic reaction is divided the following into four processes [45,46].

(1) When the energy absorbed by $g-C_{3} N_{4}$ is equal to or higher than the bandgap energy, the valence band $\mathrm{e}^{-}$in VB can be excited into $\mathrm{CB}$, and $\mathrm{h}^{+}$can be produced in VB;

(2) Under the action of the electric field, the photogenerated carrier pairs migrate to the surface of $\mathrm{g}-\mathrm{C}_{3} \mathrm{~N}_{4}$, and a part of $\mathrm{e}^{-}$and $\mathrm{h}^{+}$will be recombined in $\mathrm{g}-\mathrm{C}_{3} \mathrm{~N}_{4}$;

(3) The photogenerated $\mathrm{e}^{-}$in $\mathrm{CB}$ of $\mathrm{g}_{-} \mathrm{C}_{3} \mathrm{~N}_{4}$ can react with the dissolved oxygen in solution to form superoxide radical $\left(\mathrm{O}^{2-}\right)$, and $\mathrm{h}+$ reacts with the water molecule active hydroxyl ion adsorbed on the surface of re semiconductor to form hydroxyl radical $(\mathrm{OH})$;

(4) The generated free radicals can oxidize organics without selectivity or directly oxidize pollutants adsorbed on the surface through holes.

$$
\begin{gathered}
\text { g- } \mathrm{C}_{3} \mathrm{~N}_{4}+\mathrm{hv} \rightarrow \mathrm{g}-\mathrm{C}_{3} \mathrm{~N}_{4}+\mathrm{e}^{-}+\mathrm{h}^{+} \\
\mathrm{H}_{2} \mathrm{O}+\mathrm{h}^{+} \rightarrow \cdot \mathrm{OH}+\mathrm{H}^{+} \\
\mathrm{OH}^{-}+\mathrm{h}^{+} \rightarrow \cdot \mathrm{OH} \\
\mathrm{O}_{2}+\mathrm{e}^{-} \rightarrow \cdot \mathrm{O}_{2} \\
\mathrm{H}_{2} \mathrm{O}+\cdot \mathrm{O}^{2-} \rightarrow \cdot \mathrm{OOH}+\mathrm{OH}^{-} \\
2 \cdot \mathrm{OOH} \rightarrow \mathrm{O}_{2}+\mathrm{H}_{2} \mathrm{O}_{2}+\mathrm{OH}^{-} \\
\mathrm{H}_{2} \mathrm{O}+\mathrm{e}^{-}+\cdot \mathrm{OOH} \rightarrow \mathrm{H}_{2} \mathrm{O}_{2}+\mathrm{OH}^{-} \\
\mathrm{H}_{2} \mathrm{O}_{2}+\mathrm{e}^{-} \rightarrow \mathrm{OH}+\mathrm{OH}^{-} \\
\text {Pollutants }+\cdot \mathrm{OH}^{\rightarrow} \text { Degradation + products } \\
\text { Pollutants }+\cdot \mathrm{O}^{2-} \rightarrow \text { Degradation + products } \\
\text { Pollutants }+\mathrm{h}^{+} \rightarrow \text { Degradation + products }
\end{gathered}
$$

\section{Study on Synthesis and Modification of Graphitic Carbon Nitride Nanomaterials}

There may be two stable structures in $\mathrm{g}-\mathrm{C}_{3} \mathrm{~N}_{4}$, with triazine ring and heptazine ring as the basic structural units, respectively, forming a network structure g- $\mathrm{C}_{3} \mathrm{~N}_{4}$ (Figure 2) [47,48]. In these two structures, the layers are combined by the weak van der Waals force, and the layer spacing is $0.326 \mathrm{~nm}$. The $\mathrm{C}$ and $\mathrm{N}$ atoms are all hybridized by $\mathrm{sp}^{2}$, forming a highly delocalized elementary conjugation system through the lone pair electrons on the p-orbital [49]. Kroke et al. [50] calculated by density functional theory that the binding energy of heptazine ring is smaller than that of triazine ring structure. Consequently, 
g- $\mathrm{C}_{3} \mathrm{~N}_{4}$ with heptazine ring structure has higher stability and is considered to be the main unit structure of $\mathrm{g}-\mathrm{C}_{3} \mathrm{~N}_{4}$ stable structure.

(a)

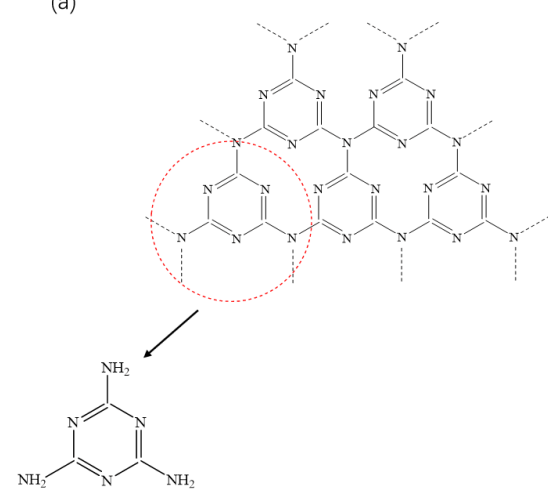

(b)

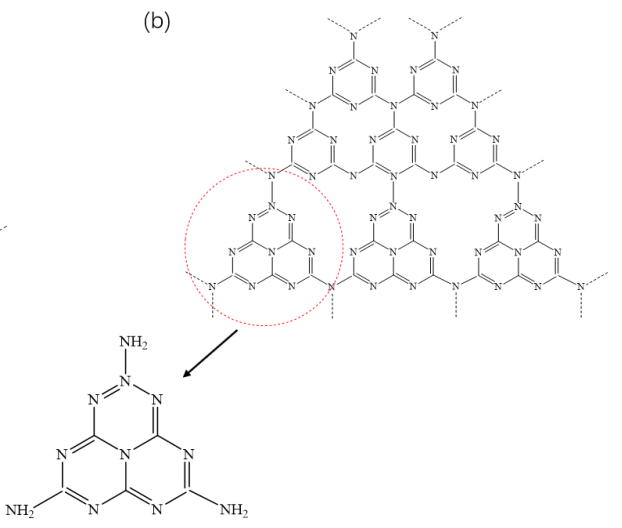

Figure 2. (a) Triazine ring unit of $g-\mathrm{C}_{3} \mathrm{~N}_{4}$; (b) The heptadazine ring unit of $g-\mathrm{C}_{3} \mathrm{~N}_{4}$.

\subsection{Synthesis of Graphitic Carbon Nitride Nanomaterials}

g- $\mathrm{C}_{3} \mathrm{~N}_{4}$ nanomaterials are usually prepared by selecting appropriate carbon and nitrogen sources (i.e., melamine, cyanuric chloride, dicyandiamide, urea and thiourea) as reactants under certain reaction conditions [51-55]. Figure 3 is a diagram of the methods currently used to prepare g- $\mathrm{C}_{3} \mathrm{~N}_{4}$. The most commonly used methods are thermal polymerization, vapor deposition, high temperature, and high-pressure synthesis and solvothermal synthesis [56-58].

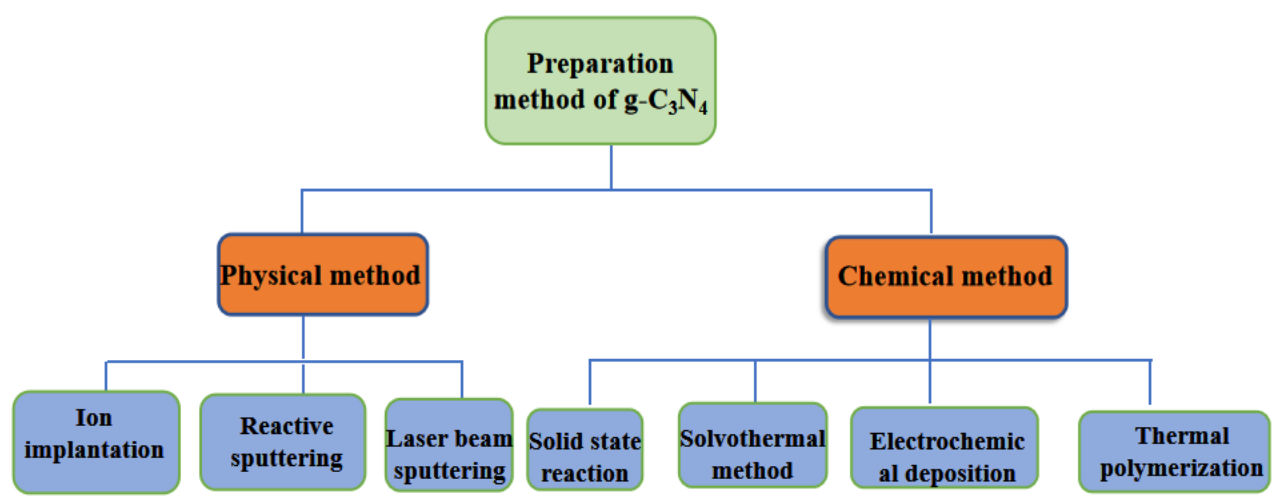

Figure 3. Graphical preparation of $\mathrm{g}-\mathrm{C}_{3} \mathrm{~N}_{4}$.

Thermal polymerization is the preparation of $\mathrm{g}-\mathrm{C}_{3} \mathrm{~N}_{4}$ by pyrolysis of nitrogen-rich organic matter and polycondensation of precursor itself. The reaction process is direct, simple, low cost and no pollution to the environment. The results show that the samples prepared by this method have good crystallinity, and the triazine structure is conducive to the growth of graphite-like crystals [59]. It is convenient to add other substances or change the reaction conditions, to adjust the structure of $g-\mathrm{C}_{3} \mathrm{~N}_{4}$ and improve the photocatalytic performance of the materials. Cui et al. [60] synthesized graphitized carbon nitride polymer by thermal polymerization at high temperature $\left(>500^{\circ} \mathrm{C}\right)$ using dicyandiamide as precursor. A certain amount of dicyandiamide was put into a crucible with a cover, calcined in a muffle furnace for $4 \mathrm{~h}$, and then cooled to room temperature to obtain the polymer. Zhang et al. [61] prepared carbon self-doped $\left(\mathrm{C}-\mathrm{g}-\mathrm{C}_{3} \mathrm{~N}_{4}\right)$ nanosheets using cyanuric acid, ethylene glycol and melamine as precursors of thermal polymerization, in which ethylene glycol was used as the solvent of cyanuric acid and melamine, and as the source of doped carbon. The results showed that the visible light absorption range of the nanosheets 
increases and the electron-hole pair separation speeds up. Wu et al. [62] utilized melamine as raw material to prepare $\mathrm{g}-\mathrm{C}_{3} \mathrm{~N}_{4}$ by thermal polymerization.

The reaction conditions of $\mathrm{g}-\mathrm{C}_{3} \mathrm{~N}_{4}$ prepared by high temperature and high-pressure synthesis method are harsh, and the requirements of reaction equipment are high Yang et al. [63] synthesized 3D porous g- $\mathrm{C}_{3} \mathrm{~N}_{4}$ heterojunction nanosheets by solid-state synthesis and high-temperature calcination. The nanosheet structure is conducive to charge transfer to the surface and provides more surface active sites, and thus exhibiting excellent photocatalytic performance. This new structure preparation method provides a new idea for other photocatalytic materials.

The vapor deposition method is divided into physical vapor deposition (PVD) and chemical vapor deposition (CVD). PVD method is a kind of thin-film preparation technology in which materials are deposited on the workpiece by physical methods in vacuum, including ion beam sputtering, ion deposition, ion plating and ion implantation. CVD mainly refers to the synthesis of coatings or nanomaterials by one or several gaseous compounds or monomers on the surface of the substrate, which can be used to prepare high-quality g- $\mathrm{C}_{3} \mathrm{~N}_{4}$ [64-66] At present, the main methods are electron cyclotron resonance, hot wire assisted, DC glow discharge, RF discharge, and indirect microwave plasma chemical vapor deposition. Dou et al. [67] deposited $g-C_{3} N_{4}$ nanosheets on cellulose-based carbonized paper by chemical vapor deposition and prepared photocatalyst mixed film, which was used to degrade dimethyl dye. The mixed film showed high activity and stability. The large surface area of the substrate is helpful to reduce the size of $g-C_{3} \mathrm{~N}_{4}$, form three-dimensional thin nanosheets, and reduce the recombination of electron-hole pairs.

Solvothermal synthesis refers to the synthesis of $g-\mathrm{C}_{3} \mathrm{~N}_{4}$ by putting the precursor and solvent together in an autoclave. The reaction temperature is relatively mild, and nitrogen is not easy to lose. Various templates can be added to control the morphology of the product, and microporous, mesoporous, and macroporous materials can be obtained. Hu et al. [68] prepared g- $\mathrm{C}_{3} \mathrm{~N}_{4}$ powder by a new microwave-assisted solvothermal synthesis method at a certain time and temperature, which had a good photocatalytic effect on the degradation of organic dyes under visible light irradiation.

\subsection{Modification of Graphitic Carbon Nitride Nanomaterials}

The bandgap value of $\mathrm{g}-\mathrm{C}_{3} \mathrm{~N}_{4}$ is about $2.7 \mathrm{eV}$, which can absorb blue-violet light with a wavelength less than $475 \mathrm{~nm}$ in the solar spectrum [69]. However, the photocatalytic effect of g- $\mathrm{C}_{3} \mathrm{~N}_{4}$ is poor due to the problems of easy recombination of photogenerated electronhole pairs, poor conductivity, limited utilization of visible light and small specific surface area. Researchers have modified $\mathrm{g}-\mathrm{C}_{3} \mathrm{~N}_{4}$ nanomaterials by template method, chemical doping and physical composite methods [70,71].

The hard template is often used as a "microreactor" in the synthesis process because of its stable structure. The precursor is filled into the pores of the hard template (anodic aluminum oxide film, porous silicon, molecular sieve, carbon nanotubes, etc.) or adsorbed on the surface of the hard template, and then the template material is removed by appropriate methods to obtain the target product [72,73]. The hard template has high stability and good narrow confinement, which can strictly control the size and morphology of nanomaterials. Different morphologies of g- $\mathrm{C}_{3} \mathrm{~N}_{4}$ (e.g., mesoporous g- $\mathrm{C}_{3} \mathrm{~N}_{4}$, hollow g- $\mathrm{C}_{3} \mathrm{~N}_{4}$, nanorods g- $\mathrm{C}_{3} \mathrm{~N}_{4}$, core-shell g- $\mathrm{C}_{3} \mathrm{~N}_{4}$ ) can be prepared by selecting different hard templates [74-77]. Luo et al. [78] prepared ordered mesoporous $\mathrm{g}^{-} \mathrm{C}_{3} \mathrm{~N}_{4}$ by using melamine as raw material, polysilicon as template, the mixture of raw material and template through thermal polymerization, and then removing polysilicon sacrificial template with a certain concentration of $\mathrm{NH}_{4} \mathrm{HF}_{2}$. The characterization and experimental results showed that the hollow g- $\mathrm{C}_{3} \mathrm{~N}_{4}$ has a large surface area, enhanced optical absorption range, good carrier separation efficiency and photocatalytic performance.

The soft template method mainly uses organic molecules of surfactants as templates, such as polyvinylpyrrolidone and sodium alkylbenzene sulfonate [79]. The soft template has no fixed rigid structure, and the intermolecular or intramolecular interactions (hydro- 
gen bond, chemical bond and electrostatic force) are used to form clusters with certain structural characteristics. The precursor forms a certain shape of nanomaterials under the action of micelles, and the template must be removed to obtain mesoporous materials just like the hard template. Sun et al. [80] used ultrastable foam as soft template to prepare micrometer porous $3 \mathrm{D} \mathrm{g}-\mathrm{C}_{3} \mathrm{~N}_{4}$ foam. In addition, $\mathrm{Cu}_{2} \mathrm{O}$ QDs were fixed onto $3 \mathrm{D} g-\mathrm{C}_{3} \mathrm{~N}_{4}$ foam by simple optical deposition strategy to obtain $\mathrm{g}-\mathrm{C}_{3} \mathrm{~N}_{4}$ foam $/ \mathrm{Cu}_{2} \mathrm{O}$ QDs composites. Characterization and photocatalytic tests of composite materials show that their unique porous structure and the interaction between $\mathrm{g}-\mathrm{C}_{3} \mathrm{~N}_{4}$ foam and $\mathrm{Cu}_{2} \mathrm{O}$ QDs have excellent photocatalytic activity.

Chemical doping can change the electronic structure of $\mathrm{g}-\mathrm{C}_{3} \mathrm{~N}_{4}$ and improve photocatalytic performance. Doping a small number of metal ions (i.e., $\mathrm{Fe}, \mathrm{Ni}, \mathrm{Ti}, \mathrm{Cu}, \mathrm{Zn}, \mathrm{Co}$ ) into the $\mathrm{g}-\mathrm{C}_{3} \mathrm{~N}_{4}$ structural unit can make it a shallow potential trapping trap of photogenerated electron-hole pair, and prolong the recombination time of electron and hole [81-84]. Nonmetallic doped elements include $\mathrm{O}, \mathrm{N}, \mathrm{P}, \mathrm{S}, \mathrm{B}, \mathrm{F}$, etc., which can replace $\mathrm{C}, \mathrm{N}, \mathrm{H}$ elements in 3-S-triazine structural unit, forming the lattice defects of $g-C_{3} N_{4}$, to achieve the effect of efficient photogenerated electron-hole pair separation [85-87]. Liu et al. [88] synthesized $\mathrm{Fe}(\mathrm{III})$-doped $\mathrm{g}-\mathrm{C}_{3} \mathrm{~N}_{4}(\mathrm{CNFex})$ by co-doping $\mathrm{Fe}(\mathrm{III})$ with amide group. The results showed that the coordination of $\mathrm{Fe}(\mathrm{III})$ can not only promote the transfer of photogenerated electrons of $\mathrm{g}-\mathrm{C}_{3} \mathrm{~N}_{4}$ but also transfer the carbon site of triazine ring, which reveals the doping mechanism and action mechanism of element metals in photocatalysis. Liu et al. [89] prepared to defect rich $\mathrm{g}-\mathrm{C}_{3} \mathrm{~N}_{4}(\mathrm{DCN})$ modified by $\mathrm{N}$-doped carbon quantum dots (NCD) and used it to degrade rhodamine $\mathrm{B}$. The results show that the modified composite has excellent photocatalytic activity, mainly because the coupling effect between NCD upconversion effect and DCN defect effect enhances the visible light response and inhibits the charge recombination.

Physical composite modification is to date the most convenient and commonly used improvement method. The selected composites mainly include semiconductor materials (i.e., metal oxides, sulfides, metal-organic frameworks), carbon materials (e.g., graphene, graphene oxide, carbon nanotubes), and metal materials (such as precious metals and bimetallic materials) [90-94]. Heterojunction can be formed between $g-\mathrm{C}_{3} \mathrm{~N}_{4}$ and the complex, which can promote the separation and transfer of interface charge. The addition of the complex can also give the catalyst some unique advantages, such as the combination of $\mathrm{g}-\mathrm{C}_{3} \mathrm{~N}_{4}$ and $\mathrm{Fe}_{3} \mathrm{O}_{4}$, which is convenient for the recycling of photocatalysts $[95,96]$.

\section{Characterization and Simulation of Graphitic Carbon Nitride Nanocomposites}

\subsection{Characterization of Graphitic Carbon Nitride Nanocomposites}

Material properties determine the application direction of materials, and the performance is often closely related to the structure and chemical composition of materials. It is important to understand the morphology, internal structure, and chemical composition of materials by characterization. The characterization of $g-C_{3} N_{4}$ matrix composites can be analyzed from three aspects: micromorphology, phase structure and composition analysis.

Micromorphology analysis refers to the analysis of the geometry, particle size distribution, composition and phase structure of the micro-region. The main analytical methods include scanning electron microscopy (SEM), transmission electron microscopy (TEM), atomic force microscope (AFM) and scanning tunnel microscope (STM). Figure 4 shows the SEM and HR-TEM images of $\mathrm{g}-\mathrm{C}_{3} \mathrm{~N}_{4} / \mathrm{RGO} / \mathrm{Fe}_{3} \mathrm{O}_{4}$. Phase analysis refers to the analysis of material composition, distribution and characteristics of each phase, including mineral type, quantity, crystal form, grain size, distribution, combination mode. The common phase analysis methods include X-ray diffraction (XRD), Raman analysis, Fourier transform infrared (FTIR), nuclear magnetic resonance (NMR), micro area electron diffraction (SAED) and ultraviolet-visible light spectroscopy (UV-Vis). Component analysis refers to the analysis of elements and impurities through techniques such as spectroscopy, mass spectroscopy, energy spectroscopy, and chromatography. Those methods include atomic absorption spectrometry (AAS), inductively coupled plasma optical emission spectrometry (ICP-OES), and 
X-ray fluorescence. Table 1 shows the basic analysis method to ascertain the morphology, phase and composition of carbon nitride-based photocatalytic nanocomposites.

Table 1. Characterization methods of morphology, phase and composition analysis of carbon nitridebased photocatalytic nanocomposites.

\begin{tabular}{|c|c|c|c|}
\hline & Technology & Analysis Content & References \\
\hline \multirow{4}{*}{$\begin{array}{l}\text { Morphology } \\
\text { analysis }\end{array}$} & SEM & $\begin{array}{l}\text { The surface or fracture morphology of the } \\
\text { sample was observed and analyzed }\end{array}$ & [97] \\
\hline & TEM & $\begin{array}{l}\text { Provide the internal structure information of } \\
\text { the sample, such as crystal structure, } \\
\text { morphology and stress state }\end{array}$ & [98] \\
\hline & AFM & $\begin{array}{l}\text { The three-dimensional appearance image of } \\
\text { the sample surface can be obtained, and the } \\
\text { roughness calculation, thickness, or particle } \\
\text { size analysis of the three-dimensional } \\
\text { appearance image can be carried out }\end{array}$ & [99] \\
\hline & STM & $\begin{array}{l}\text { The characteristic image of atomic level } \\
\text { sample surface morphology was obtained }\end{array}$ & [100] \\
\hline \multirow{6}{*}{$\begin{array}{l}\text { Phase } \\
\text { analysis }\end{array}$} & $\mathrm{XRD}$ & $\begin{array}{l}\text { Through the preliminary qualitative analysis } \\
\text { of the material, the name and chemical } \\
\text { formula of the material are determined }\end{array}$ & [101] \\
\hline & Raman & $\begin{array}{l}\text { The chemical structure, morphology, } \\
\text { crystallinity and molecular interaction of the } \\
\text { samples were analyzed }\end{array}$ & [102] \\
\hline & FTIR & Analysis of group structure of materials & [103] \\
\hline & NMR & $\begin{array}{l}\text { Study the molecular structure, conformation, } \\
\text { molecular dynamics, etc. }\end{array}$ & [104] \\
\hline & SAED & $\begin{array}{l}\text { The morphology and structure of the selected } \\
\text { region in the sample were analyzed }\end{array}$ & [105] \\
\hline & UV-Vis & $\begin{array}{l}\text { The absorption range of the photocatalyst } \\
\text { material is reflected, and the energy bandgap } \\
\text { of the photocatalyst is calculated by the } \\
\text { subsequent formula conversion }\end{array}$ & [103] \\
\hline \multirow{3}{*}{$\begin{array}{l}\text { Component } \\
\text { analysis }\end{array}$} & AAS & $\begin{array}{l}\text { Qualitative and quantitative analysis of the } \\
\text { elements to be determined }\end{array}$ & [106] \\
\hline & ICP-OES & $\begin{array}{l}\text { Qualitative and quantitative analysis of } \\
\text { various metal elements and some non-metal } \\
\text { elements were carried out }\end{array}$ & [107] \\
\hline & XRF & $\begin{array}{l}\text { Simultaneous determination of major, minor } \\
\text { and trace elements in solid samples }\end{array}$ & [108] \\
\hline
\end{tabular}

In addition to the above-mentioned characterization techniques, this review also summarizes the important properties of carbon nitride-based photo-catalytic nanocomposites (e.g., electron-hole separation, charge dynamics, defects, energy band structure), characterization methods of reaction intermediates, and their intermediates after degradation of pollutants are summarized (below).

Commonly used techniques to characterize electron-hole separation are electrochemical impedance spectroscopy (EIS), photocurrent response analysis, steady-state photoluminescence (PL), time-resolved transient fluorescence (TRF), and ultrafast transient absorption (TA) [109-113]. EIS is broadly considered an effective means to evaluate the ability of photoinduced carrier separation. The resistance of charge transfer can be judged by comparing the radius of the semicircle area. The smaller the radius, the smaller the impedance of charge transfer, and the higher the charge separation degree. Photocurrent response analysis means that when the material is excited by light energy, the valence band electrons are excited and jump to the conduction band. Under the action of strong electric field, the conduction band electrons will move in a directional direction to form photocurrent. Higher photocurrent response indicates better charge separation performance. The 
recombination degree of photogenerated electron and hole can be determined by the peak intensity of PL spectrum. TRF can obtain time-resolved fluorescence spectrum by testing, analyze and fit the fluorescence lifetime, to obtain the separation effect of photogenerated electrons and holes. TA means that high-energy pump light is used to excite the material in the ground state to the excited state, and then a low-energy probe light is used to detect the relaxation process of the excited state level particles. The relaxation time represents the length of the electron lifetime, which can be used to analyze the dynamics of particles with very short lifetime.
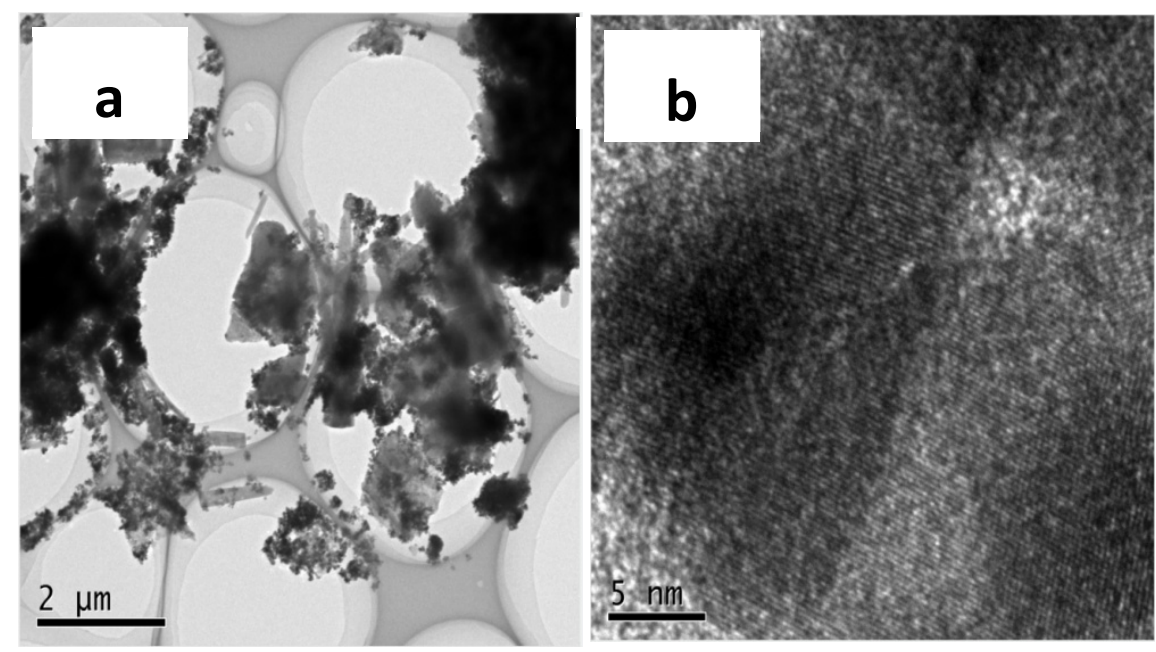

Figure 4. HR-TEM (a), SEM (b) images of $\mathrm{g}-\mathrm{C}_{3} \mathrm{~N}_{4} / \mathrm{RGO} / \mathrm{Fe}_{3} \mathrm{O}_{4}$.

When the material is excited by light, the separation and migration of photogenerated electrons and holes are very important for the photocatalytic activity of the material. Cui et al. [114] synthesized $\mathrm{WO}_{3} / \mathrm{g}-\mathrm{C}_{3} \mathrm{~N}_{4}$ composite photocatalyst from urea to degrade rhodamine $\mathrm{B}$ under visible light irradiation. The results showed that the photocatalytic activity of $\mathrm{WO}_{3} / \mathrm{g}-\mathrm{C}_{3} \mathrm{~N}_{4}$ composite is better than that of pure $\mathrm{WO}_{3}, \mathrm{~g}-\mathrm{C}_{3} \mathrm{~N}_{4}$, and other $\mathrm{WO}_{3} / \mathrm{g}-\mathrm{C}_{3} \mathrm{~N}_{4}$ materials. Based on the comparative analysis of EIS and PL, a possible Z-type photocatalysis mechanism is proposed, which can well explain the enhancement mechanism of photogenerated electron and hole mobility in composite heterostructures. Cui et al. [115] controlled the morphology of $g-C_{3} N_{4}$ and prepared carbon nitride with onion ring morphology. The main reason was that the catalyst with onion ring morphology is conducive to the separation of photogenerated carriers. Photocurrent analysis showed that the photogenerated electrons were separated effectively, and PL analysis showed that the recombination of photogenerated electrons and holes was significantly inhibited. Combined with photocurrent analysis, PL and EIS, the important influence of morphology control on photogenerated electron-hole separation of carbon nitride was explored.

Characterization of reaction intermediates includes capture and quenching of reaction intermediates, detection and analysis, etc. Active substance capture experiment by adding active substance capture agent in the photocatalytic system to study the change of photocatalytic performance, we can confirm which active substance plays the role of photocatalysis [116]. The fluorescent labeling method uses free radicals to react specifically with some substances to produce substances with fluorescent properties. By adding this fluorescent marker in the photocatalytic reaction, and then using the fluorescence spectrum to test after the reaction, the type of free radicals can be determined [117]. Electron paramagnetic resonance (ESR) is used to analyze the types of free radicals in the process of photocatalysis, and the determination process is fast, direct and effective [118]. GC-MS and LC-MS can identify the intermediate products after photocatalytic degradation of pollutants, to deduce the possible degradation pathway. With high resolution and sensitivity, GC-MS is widely used in the separation and identification of complex components. It is an effective tool 
for qualitative and quantitative analysis of drugs and metabolites in biological samples. LC-MS is mainly used in drug metabolism, pharmacokinetics, natural drug development, residue analysis and toxicological analysis. Tang et al. [119] prepared double $\mathrm{Z}$ scheme g- $\mathrm{C}_{3} \mathrm{~N}_{4} / \mathrm{Ag}_{3} \mathrm{PO}_{4} / \mathrm{AgI}$ composite photocatalyst by in situ ion exchange method of $\mathrm{Z}$ scheme $\mathrm{Ag}_{3} \mathrm{PO}_{4} / \mathrm{g}-\mathrm{C}_{3} \mathrm{~N}_{4}$. Compared with pure g- $\mathrm{C}_{3} \mathrm{~N}_{4}$, silver phosphate, silver iodide and their binary composites, the double Z-type photocatalyst has a better degradation effect in the degradation of pyrazine. The results of PL and transient photocurrent response showed that the separation efficiency of photo-induced electrons and pores of the composite is significantly improved, which was conducive to improving its photocatalytic activity. The active species capture experiment and ESR showed that the main active substances for nitenpyram degradation were $\mathrm{O}^{2-}$ and $\mathrm{h}^{+}$. The possible degradation pathway of nitenpyram was deduced by LC-MS. Under the continuous attack of $\mathrm{O}^{2-}$ and other active species, nitenpyram was finally oxidized into carbon dioxide and water.

\subsection{Numerical Simulation and Characterization of Graphitic Carbon Nitride Nanocomposites}

The data of microstructure, physicochemical properties, and characterization parameters of materials can be obtained by calculation, which is a supplement and in-depth excavation to the traditional material science dominated by experiments. The combination of computational simulation and test characterization can verify the experimental results or explain the mechanism. Commonly used calculation and simulation methods include density functional first-principles calculations, molecular dynamics and Monte Carlo methods [120].

The first-principles calculation is based on spin-polarized density functional theory (DFT), which was proposed by Perdew, Burke and Ernzerhof. The calculation does not rely on any empirical parameters, only needs to know the atomic species of each element in the microscopic system, and directly solve the Schrodinger equation through DFT calculation software [121,122]. In the computational material, by optimizing its geometric structure and calculating the energy of the system, important information such as the energy band structure, the density of states, and the charge distribution is obtained, and then the system is analyzed quantitatively in theory. Shi et al. [123] successfully synthesized the g- $\mathrm{C}_{3} \mathrm{~N}_{4} / \mathrm{NaNbO}_{3}$ nanowire composite photocatalyst. DFT and Mulliken electronegativity calculations show that the conduction band bottom and valence band top potentials of $\mathrm{NaNbO}_{3}$ and g- $\mathrm{C}_{3} \mathrm{~N}_{4}$ are $-0.77,2.63$ and -1.13 and $1.57 \mathrm{eV}$, respectively. Wang et al. [124] proposed a metal-free $\mathrm{C}_{3} \mathrm{~N} / \mathrm{g}-\mathrm{C}_{3} \mathrm{~N}_{4}$ heterojunction and explored its electronic structure, charge distribution and photocatalytic performance through DFT calculations. The results show that the $\mathrm{C}_{3} \mathrm{~N} / \mathrm{g}-\mathrm{C}_{3} \mathrm{~N}_{4}$ heterojunction is expected to be a direct Z-scheme photocatalyst, which is due to the band bending caused by charge transfer between $C_{3} \mathrm{~N}$ and g- $\mathrm{C}_{3} \mathrm{~N}_{4}$. In addition, the photogenerated electron and hole heterojunction in $\mathrm{C}_{3} \mathrm{~N} / \mathrm{g}-\mathrm{C}_{3} \mathrm{~N}_{4}$ can not only be effectively separated, the visible light absorption range is significantly enhanced, but also has a strong redox ability.

Molecular dynamics is a computational method based on the statistical mechanics of classical physics. By solving the intermolecular interaction potential function and the equation of motion, it gives the relationship between the microscopic quantity and the macroscopic observability, thus study the equilibrium and mechanical properties of the composite system. Wang et al. [125] prepared B-doping in $\mathrm{g}-\mathrm{C}_{3} \mathrm{~N}_{4}$ nanosheets (BCN) by introducing boron into g- $\mathrm{C}_{3} \mathrm{~N}_{4}$. Experiments results and molecular dynamics simulation showed that the B-N-C bond constructed by B-doping can not only anchor the exposed active $\mathrm{N}$ atoms on the surface of carbon nitride stably but also effectively inhibit the photogenerated carrier recombination of $\mathrm{g}-\mathrm{C}_{3} \mathrm{~N}_{4}$ by forming a nano-level p-n junction. $\mathrm{N}_{2}$ chemisorption test and molecular dynamics simulation show that the introduction of $\mathrm{B}$ atom site becomes the active site of $\mathrm{N}_{2}$ molecular adsorption and activation, which is conducive to the photocatalytic reaction.

The Monte Carlo method is a random sampling statistical method based on probability theory and mathematical statistics, which uses random numbers (or more common pseudo- 
random numbers) to solve practical problems. It is often used to solve some real-life problems with "random" properties and study some experiments with physical quantities that are difficult to observe under current conditions. According to the law of large numbers, a large number of repeated experiments are needed to make random independent events present statistical results with certain regularity [126]. Chen et al. [127] prepared single atom heterogeneous catalysts by adding metals (Pd, $\mathrm{Ag}$, Ir, $\mathrm{Pt}$ or $\mathrm{Au}$ ) into different forms of g- $\mathrm{C}_{3} \mathrm{~N}_{4}$ (block, mesoporous and spalling form). Employing density functional theory and dynamic Monte Carlo simulation, the dispersion of different metals is rationalized, and the interaction between adsorption energetics and diffusion kinetics is emphasized. The evaluation of the continuous three-phase semi hydrogenation of 1-hexene shows that controlling the metal carrier interaction and the metal sites exposed to the surface layer are the key challenges in the design of efficient Sachs.

\section{Application of Graphitic Carbon Nitride Photocatalytic Nanocomposites in Organic Wastewater Treatment}

Photocatalytic technology has been widely concerned by researchers in wastewater treatment. It can transform organic pollutants into small molecules of $\mathrm{CO}_{2}$ and water through an oxidation-reduction reaction. It is an ideal green technology with great application value and potential. In wastewater treatment, carbon nitride-based photocatalytic nanocomposites mainly treat dye wastewater (Rhodamine B, methylene blue, etc.) and pharmaceutical wastewater (antibiotics and pesticides). The specific utilization is summarized in Table 2.

Table 2. $\mathrm{g}-\mathrm{C}_{3} \mathrm{~N}_{4}$ composites and their photocatalytic degradation of organic pollutants.

\begin{tabular}{|c|c|c|c|c|c|c|}
\hline Composite & Pollutant & $\begin{array}{c}\text { Percentage } \\
\text { Degradation }\end{array}$ & $\begin{array}{l}\text { Reaction } \\
\text { Time }\end{array}$ & Source & $\begin{array}{l}\text { Oxidizing } \\
\text { Species }\end{array}$ & Reference \\
\hline $\mathrm{g}-\mathrm{C}_{3} \mathrm{~N}_{4} / \mathrm{TiO}_{2}$ & phenol & $16.5 \%$ & $120 \mathrm{~min}$ & visible light $(>420 \mathrm{~nm})$ & $\mathrm{O}^{2-}$ & [128] \\
\hline $\begin{array}{l}\text { mesoporous } \\
\text { carbon nitride }\end{array}$ & $\begin{array}{l}\text { amoxicillin and } \\
\text { cefotaxime }\end{array}$ & $40 \%, 80 \%$ & $60 \mathrm{~min}$ & $\begin{array}{l}300 \mathrm{~W} \text { xenon lamp } \\
\text { (with filter }>420 \mathrm{~nm} \text { ) }\end{array}$ & $\mathrm{O}^{2-}$ & [129] \\
\hline $\mathrm{N}-\mathrm{TiO}_{2} / \mathrm{CNONV}-2$ & $\begin{array}{c}\text { tetracycline } \\
\text { hydrochloride }\end{array}$ & $79.9 \%$ & $160 \mathrm{~min}$ & visible light & $\mathrm{O}^{2-}$ and $\mathrm{h}^{+}$ & [130] \\
\hline $\begin{array}{l}\text { Cl-doped porous } \\
\text { g- }-\mathrm{C}_{3} \mathrm{~N}_{4}\end{array}$ & tetracycline & $92 \%$ & $120 \mathrm{~min}$ & $300 \mathrm{~W}$ xenon lamp & $\mathrm{O}^{2-}$ and $\mathrm{h}^{+}$ & {$[131]$} \\
\hline $\mathrm{CDs} / \mathrm{g}-\mathrm{C}_{3} \mathrm{~N}_{4} / \mathrm{SnO}_{2}$ & indomethacin & $90.8 \%$ & $80 \mathrm{~min}$ & $350 \mathrm{~W}$ xenon lamp & $\mathrm{O}^{2-}$ and $\mathrm{h}^{+}$ & [132] \\
\hline $\mathrm{g}-\mathrm{C}_{3} \mathrm{~N}_{4}(1.5 w \mathrm{t} . \%) / \mathrm{HAp}$ & tetracycline & $100 \%$ & $15 \mathrm{~min}$ & $300 \mathrm{~W}$ Xe arc lamp & $\mathrm{O}^{2-}$ and $\mathrm{h}^{+}$ & {$[133]$} \\
\hline $\begin{array}{c}\text { GQdots } / \mathrm{Mn}-\mathrm{N}-\mathrm{TiO}_{2} / \mathrm{g}- \\
\qquad \mathrm{C}_{3} \mathrm{~N}_{4}\end{array}$ & ciprofloxacin & $89 \%$ & $120 \mathrm{~min}$ & 300 W Xe lamp & $\mathrm{OH}$ & [134] \\
\hline $\mathrm{Ag}_{3} \mathrm{PO}_{4} / \mathrm{GO} / \mathrm{g}-\mathrm{C}_{3} \mathrm{~N}_{4}$ & rhodamine B & $94.8 \%$ & $50 \mathrm{~min}$ & visible light & $\mathrm{OH}, \mathrm{O}^{2-}$ and $\mathrm{h}^{+}$ & [135] \\
\hline POCN/anatase $\mathrm{TiO}_{2} 1-1$ & enrofloxacin & $98.5 \%$ & $60 \mathrm{~min}$ & $350 \mathrm{~W}$ xenon lamp & $\mathrm{O}^{2-}$ and $\mathrm{h}^{+}$ & [136] \\
\hline CoP-HCCN & tetracycline & $96.7 \%$ & $120 \mathrm{~min}$ & visible light & $\mathrm{OH}, \cdot \mathrm{O}^{2-}$ and $\mathrm{h}^{+}$ & [137] \\
\hline $\mathrm{WO}_{3} / g-\mathrm{C}_{3} \mathrm{~N}_{4} / \mathrm{Bi}_{2} \mathrm{O}_{3}$ & $\begin{array}{l}\text { tetracycline } \\
\text { ten typical }\end{array}$ & $80.2 \%$ & $60 \mathrm{~min}$ & 300 W Xe lamp & $\mathrm{OH}, \cdot \mathrm{O}^{2-}$ and $\mathrm{h}^{+}$ & {$[138]$} \\
\hline $\begin{array}{l}\text { Oxygen functional } \\
\text { carbon nitride }\end{array}$ & $\begin{array}{l}\text { herbicides (e.g., } \\
\text { acetochlor, } \\
\text { pretilachlor) }\end{array}$ & N.A. & $>180 \mathrm{~min}$ & $\begin{array}{l}\text { visible-light } \\
(\lambda>400 \mathrm{~nm})\end{array}$ & $\mathrm{OH}, \mathrm{h}^{+}$ & [139] \\
\hline \multirow{2}{*}{$\begin{array}{c}\mathrm{g}-\mathrm{C}_{3} \mathrm{~N}_{4} / \mathrm{Bi}_{4} \mathrm{O}_{5} \mathrm{I}_{2} \\
\mathrm{CeO}_{2} / \mathrm{g}-\mathrm{C}_{3} \mathrm{~N}_{4} \\
\text { nanosheet }\end{array}$} & methyl orange & $0.164 \mathrm{~min}^{-1}$ & $50 \mathrm{~min}$ & visible light & $\mathrm{O}^{2-}$ and $\mathrm{h}^{+}$ & [140] \\
\hline & toward bisphenol A & $93.7 \%$ & $80 \mathrm{~min}$ & 300 W Xe lamp & $\mathrm{O}^{2-}$ and $\mathrm{h}^{+}$ & {$[141]$} \\
\hline
\end{tabular}

Deng et al. [142] prepared CD-rGO-O-g/ $\mathrm{C}_{3} \mathrm{~N}_{4}$ by adjusting energy band, optimizing charge extraction and decorating cocatalyst to change the photocatalytic behavior of $\mathrm{g} / \mathrm{C}_{3} \mathrm{~N}_{4}$, and used it to degrade lincomycin. The results show that the degradation rate of the optimized photocatalyst is ten times higher than that of the original $g / C_{3} N_{4}$. $\mathrm{Li}$ et al. [143] introduced $\mathrm{Cu}^{2+}$ into g- $\mathrm{C}_{3} \mathrm{~N}_{4}$ to improve the photocatalytic degradation activity of $\mathrm{g}-\mathrm{C}_{3} \mathrm{~N}_{4}$. The doped $\mathrm{Cu}^{2+}$ can be used as an electron capture site, which is helpful for the separation of photogenerated electron-hole pairs and the interface charge transfer. The degradation of rhodamine $\mathrm{B}$ by $\mathrm{Cu} / \mathrm{g}-\mathrm{C}_{3} \mathrm{~N}_{4}$ and $\mathrm{g}-\mathrm{C}_{3} \mathrm{~N}_{4}$ monomers was investigated, and the mechanism of Rhodamine $\mathrm{B}$ degradation was studied by radical capture experiment. Deng et al. [144] designed and synthesized unique ultra-thin 1D/2D $\mathrm{W}_{18} \mathrm{O}_{49} / \mathrm{g}-\mathrm{C}_{3} \mathrm{~N}_{4}$ 
nanocomposites through reasonable band structure and multi-scale structure, and used them for the degradation of ibuprofen. The results show that the composite has a good photocatalytic degradation ability of ibuprofen under simulated standard sunlight (the removal rate of IBF can reach $96.3 \%$ under am $1.5 \mathrm{~g}$ illumination for $60 \mathrm{~min}$ ), and the degradation ability of ibuprofen under near-infrared illumination is also better than that of pure $g-\mathrm{C}_{3} \mathrm{~N}_{4}$ and $\mathrm{W}_{18} \mathrm{O}_{49}$ (under near-infrared illumination for $120 \mathrm{~min}$, the degradation rate of IBF is higher than that of pure $\mathrm{g}-\mathrm{C}_{3} \mathrm{~N}_{4}$ and $\mathrm{W}_{18} \mathrm{O}_{49}$ ), The degradation rate of IDF by UWN-3 was $39.2 \%$.

To improve the utilization rate of carbon nitride nanocomposite materials, the nanomaterials can be recovered by recycling equipment, magnetic separation, precipitation, and other methods. Chu et al. [145] designed a specific device to recover the photocatalyst supported by $\mathrm{g}-\mathrm{C}_{3} \mathrm{~N}_{4}$ /active carbon fiber. The results show that the modified device is suitable for the high-efficiency and recyclable treatment of organic wastewater, which opens up a feasible way for the development of high-efficiency photocatalytic technology that can recycle and degrade environmental pollutants. Kumar et al. [146] used magnetic materials to recycle $\mathrm{TACN} / \mathrm{TiO}_{2} / \mathrm{Fe}_{3} \mathrm{O}_{4} @ \mathrm{SiO}_{2}$ nanocomposite materials. The recovered materials can be recycled within $5 \mathrm{~h}$ without calcination or heating, and the photocatalytic efficiency remains above $83 \%$ after five cycles.

\section{Artificial Intelligence Prediction and Optimization}

Modeling and optimization of photocatalytic degradation of wastewater by neural network is a hot topic in this field [147]. It is essentially a parallel distribution and can mimic the human brain's information processing system in varying degrees and levels. It adopts a completely different mechanism from traditional information processing technology and overcomes the shortcomings of processing intuition and unstructured information. This has the characteristics of self-adaptation, self-organization and real-time learning, so it can predict complex multi-dimensional problems in catalysis [148,149]. At present, the most common neural networks are perceptron network, BP network, genetic algorithm neural network, particle swarm optimization neural network, radial basis function neural network.

The artificial neural network has been proved to be an effective method to develop complex nonlinear prediction model, which can predict the effect of catalyst dosage, $\mathrm{pH}$ value, time and other factors on the degradation effect, and obtain the optimal reaction conditions. Dorraji et al. [150] synthesized polymer $\mathrm{g}-\mathrm{C}_{3} \mathrm{~N}_{4}$ by heating with melamine as precursor and used it for degradation of Reactive Black 5. They used an artificial neural network to establish the relationship between input independent variables and output dependent variables. They utilized an artificial neural network to establish the relationship between input variables and output variables, and combined with genetic algorithm to model and optimize the four operation parameters $\left(\mathrm{pH}\right.$, initial dye concentration, $\mathrm{g}-\mathrm{C}_{3} \mathrm{~N}_{4}$ dosage and time) in the process of photocatalytic degradation, to obtain the optimal operation conditions. Gupta et al. [151] utilized the prepared $3 \mathrm{D} S-\mathrm{C}_{3} \mathrm{~N}_{4} / \mathrm{ZnO}$ to degrade ciprofloxacin and predicted the optimal experimental conditions with the help of neural network multivariable method. The input value and target value are set as the experimental conditions of five parameters (catalyst dosage, $\mathrm{pH}$, initial concentration, temperature and time) and the corresponding degradation rate. Through comparing predicted value, experimental value, error value, Marquardt's percent standard deviation and $\mathrm{X}^{2}$ square test statistics to get the best experimental conditions.

\section{Concluding Remarks and Future Outlook}

The present study systematically introduces the basic catalytic principle, preparation, modification, characterization and computational simulation of carbon nitride-based photocatalysis composites. It is also summarized for the latest research progress of them with the aid of artificial intelligence tools in wastewater treatment. To sum up, some promising results have been reported so far, but the research in this field is still in the initial stage, which needs further development. It is worth noting that the photocatalytic efficiency 
of composite materials is relatively low, and the stability is poor. There are still some challenges in preparing high-performance carbon nitride-based photocatalysts. In addition, its photocatalytic mechanism needs to be studied in depth. Based on the above discussion, the related issues to be further studied and clarified in the future are as follows:

(1) With the help of new characterization techniques, the charge transfer path and photocatalytic mechanism of carbon nitride-based composites were further elucidated, such as X-ray absorption spectrum fine structure, high-energy resolution fluorescencedetected X-ray absorption spectroscopy, vacuum ultraviolet photoionization mass spectrometry, photoelectric emission technology, angle-resolved photoelectron spectroscopy, and material structure analysis;

(2) DFT theoretical calculation is more widely used in the field of photocatalysis, which can provide important information support for elucidating the optimal performance of modified $\mathrm{g}-\mathrm{C}_{3} \mathrm{~N}_{4}$ and predicting its catalytic reaction efficiency;

(3) The application of intelligent nanodevices (e.g., micro-robots) combined with photocatalyst in wastewater treatment can quickly remove pollutants in wastewater and can be recycled after recycling, which is expected to bring an efficient and economic wastewater purification method.

Author Contributions: Conceptualization and funding acquisition, X.H.; writing-review and editing, C.L. and X.W.; literature search, J.L.; drawing, J.S.; supervision, X.H. All authors have read and agreed to the published version of the manuscript.

Funding: This work was financially supported by the Guizhou Science and Technology Support Plan Project (No. [2019] 1217); the China Postdoctoral Science Foundation (No. 2020M673582XB), the Guizhou Forestry Research (No. [2017] 17) and the Guizhou Science and Technology (No. [2017] 7371).

Institutional Review Board Statement: Not applicable.

Informed Consent Statement: Not applicable.

Data Availability Statement: Data is contained within the article.

Conflicts of Interest: The authors declared no conflict of interest.

\section{References}

1. We, A.; Aris, A.; Zain, N. A review of the treatment of low-medium strength domestic wastewater using aerobic granulation technology. Environ. Sci. Water Res. Technol. 2020, 6, 464-490. [CrossRef]

2. Khan, W.; Nam, J.Y.; Byun, S. Emerging investigator series: Quaternary treatment with algae-assisted oxidation for antibiotics removal and refractory organics degradation in livestock wastewater effluent. Environ. Sci. Water Res. Technol. 2020, 6, 3262-3275. [CrossRef]

3. Dharupaneedi, S.P.; Nataraj, S.K.; Nadagouda, M.; Reddy, K.R.; Shukla, S.S.; Aminabhavi, T.M. Membrane-based separation of potential emerging pollutants. Sep. Purif. Technol. 2019, 210, 850-866. [CrossRef] [PubMed]

4. Chen, C.; Cheng, T.; Zhang, X.; Wu, R.; Wang, Q. Synthesis of an efcient Pb adsorption nano-crystal under strong alkalihydrothermal environment using a gemini surfactant as directing agent. J. Chem. Soc. Pak. 2019, 41, 1034-1038.

5. Yao, N.; Chen, C.; Li, D.J.; Hu, Y.L. Cobalt nanoparticles embedded over periodic mesoporous organosilica functionalized with benzotriazolium ionic liquid for efficient and heterogeneous catalytic transformation of carbon dioxide to cyclic carbonates. $J$. Environ. Chem. Eng. 2020, 8, 103953. [CrossRef]

6. Feng, L.; Astruc, D. Nanocatalysts and other nanomaterials for water remediation from organic pollutants. Coord. Chem. Rev. 2020, 408, 213180.

7. Chen, D.; Cheng, Y.; Zhou, N.; Chen, P.; Wang, Y.; Li, K.; Huo, S.; Cheng, P.; Peng, P.; Zhang, R.; et al. Photocatalytic degradation of organic pollutants using tio2-based photocatalysts: A review. J. Clean. Prod. 2020, 268, 121725. [CrossRef]

8. Hou, Y.; Qi, J.M.; Hu, J.W.; Xiang, Y.Q.; Xin, L.; Wei, X.H. Mesoporous Mn-Fe nanoparticles modified reduced graphene oxide for ethyl violet elimination: Modeling and optimization using artificial intelligence. Processes 2020, 8, 488. [CrossRef]

9. Qi, J.M.; Hou, Y.; Hu, J.W.; Ruan, W.Q.; Xiang, Y.Q.; Wei, X.H. Decontamination of methylene blue from simulated wastewater by the mesoporous rGO/Fe/Co nanohybrids: Artificial intelligence modeling and optimization. Mater. Today Commun. 2020, 241, 100709. [CrossRef]

10. Chen, C.; Cheng, T.; Shi, Y.S.; Tian, Y. Adsorption of $\mathrm{Cu}(\mathrm{II})$ from aqueous solution on fy ash based linde F(K) Zeolite. Iran. J. Chem. Chem. Eng. 2014, 33, 29-35. 
11. Cheng, T.; Chen, C.; Tang, R.; Han, C.H.; Tian, Y. Competitive adsorption of $\mathrm{Cu}, \mathrm{Ni}, \mathrm{Pb}$ and Cd from aqueous solution onto fly ash-based Linde $\mathrm{F}(\mathrm{K})$ zeolite. Iran. J. Chem. Chem. Eng. 2018, 37, 61-71.

12. Yuan, D.; Zhang, C.; Tang, S.; Li, X.; Zhang, Q. Enhancing $\mathrm{CaO}_{2}$ fenton-like process by Fe(II)-oxalic acid complexation for organic wastewater treatment. Water Res. 2019, 163, 114861. [CrossRef] [PubMed]

13. Marouek, J.; Kolá, L.; Struneck, O.; Kopeck, M.; Vrbka, J. Modified biochars present an economic challenge to phosphate management in wastewater treatment plants. J. Clean. Prod. 2020, 272, 123015. [CrossRef]

14. Arzate, S.; Pfister, S.; Oberschelp, C.; Sanchez-Perez, J.A. Environmental impacts of an advanced oxidation process as tertiary treatment in a wastewater treatment plant. Sci. Total Environ. 2019, 694, 133572. [CrossRef]

15. Yahya, E.; Keivan, S.; Ahmad, T.; Aptin, R.; Farid, G.F. Effective removal of cefazolin from hospital wastewater by the electrocoagulation process. Water Sci. Technol. 2019, 80, 2422-2429.

16. Wulansarie, R.; Bismo, S.; Azis, I.A.; Rahmadhani, D. Degradation of Wastewater Containing Amoxicillin Antibiotic Using Green Technology “Ozonation”. IOP Conf. Ser. Mater. Sci. Eng. 2020, 982, 012039. [CrossRef]

17. Li, Y.; Hui, D.; Sun, Y. Boosting thermo-photocatalytic $\mathrm{CO}_{2}$ conversion activity by using photosynthesis-inspired electron-protontransfer mediators. Nat. Commun. 2021, 12, 123. [CrossRef]

18. Guo, S.; Li, X.; Li, J. Boosting photocatalytic hydrogen production from water by photothermally induced biphase systems. Nat. Commun. 2021, 12, 1343. [CrossRef]

19. Hu, Z.; Li, X.; Zhang, S.; Li, Q.; Fan, J.; Qu, X. Fe/TiO 2 hollow microspheres: Fe and Ti dual active sites boosting the photocatalytic oxidation of NO. Small 2020, 16, 2004583. [CrossRef]

20. Ji, J.; Yan, Q.; Yin, P.; Mine, S.; Matsuoka, M.; Xing, M. Tuning redox reactions via defects on $\operatorname{CoS}_{2}$-x for sustainable degradation of organic pollutants. Angew. Chem. 2021, 133, 2939-2944. [CrossRef]

21. Guo, Q.; Zhou, C.; Ma, Z.; Yang, X. Fundamentals of $\mathrm{TiO}_{2}$ photocatalysis: Concepts, mechanisms, and challenges. Adv. Mater. 2019, 31, 1901997. [CrossRef] [PubMed]

22. Wu, Q.; Liu, Y.; Jing, H.; Yu, H.; Huo, H. Peculiar synergetic effect of $\gamma$ - $-\mathrm{Fe}_{2} \mathrm{O}_{3}$ nanoparticles and graphene oxide on mil-53 (Fe) for boosting photocatalysis. Chem. Eng. J. 2020, 390, 124615. [CrossRef]

23. Gu, X.; Li, C.; Yuan, S.; Ma, M.; Qiang, Y.; Zhu, J. ZnO based heterojunctions and their application in environmental photocatalysis. Nanotechnology 2016, 27, 402001. [CrossRef]

24. He, W.; Sun, Y.; Jiang, G.; Huang, H.; Zhang, X.; Dong, F. Activation of amorphous $\mathrm{Bi}_{2} \mathrm{WO}_{6}$ with synchronous bi metal and $\mathrm{Bi}_{2} \mathrm{O}_{3}$ coupling: Photocatalysis mechanism and reaction pathway. Appl. Catal. B Environ. 2018, 232, 340-347. [CrossRef]

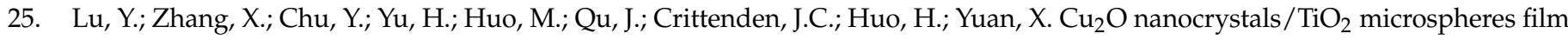
on a rotating disk containing long-afterglow phosphor for enhanced round-the-clock photocatalysis. Appl. Catal. B Environ. 2018, 224, 239-248. [CrossRef]

26. Zheng, N.C.; Ouyang, T.; Chen, Y.; Zhu, W.; Chen, D.Y.; Liu, Z.Q. Ultrathin CdS shell sensitized hollow S-doped CeO 2 spheres for efficient visible-light photocatalysis. Catal. Sci. Technol. 2019, 9, 1357-1364. [CrossRef]

27. Stavrou, E.; Lobanov, S.; Dong, H.; Oganov, A.R.; Prakapenka, V.B.; Konopkova, Z. Cheminform abstract: Synthesis of ultraincompressible $\mathrm{sp}^{3}$-hybridized carbon nitride with 1:1 stoichiometry. J. Cheminformatics 2016, 28, 6925-6933. [CrossRef]

28. He, L.; Fei, M.; Chen, J.; Tian, Y.; Chen, L. Graphitic $\mathrm{C}_{3} \mathrm{~N}_{4}$ quantum dots for next-generation qled displays. Mater. Today 2018, 22, 76-84. [CrossRef]

29. Ong, W.J.; Tan, L.L.; Ng, Y.H.; Yong, S.T.; Chai, S.P. Graphitic carbon nitride $\left(\mathrm{g}-\mathrm{C}_{3} \mathrm{~N}_{4}\right)$-based photocatalysts for artificial photosynthesis and environmental remediation: Are we a step closer to achieving sustainability? Chem. Rev. 2016, 116, 7159-7329. [CrossRef]

30. Chen, D.; Li, B.; Pu, Q.; Chen, X.; Wen, G.; Li, Z. Preparation of Ag-AgVO $3 / g-C_{3} N_{4}$ composite photo-catalyst and degradation characteristics of antibiotics. J. Hazard. Mater. 2019, 373, 303-312. [CrossRef]

31. Liu, X.; Ma, R.; Zhuang, L.; Hu, B.; Chen, J.; Liu, X. Recent developments of doped g- $\mathrm{C}_{3} \mathrm{~N}_{4}$ photocatalysts for the degradation of organic pollutants. Crit. Rev. Environ. Sci. Technol. 2020, 51, 751-790. [CrossRef]

32. Wang, C.C.; Yi, X.H.; Wang, P. Powerful combination of mofs and $\mathrm{C}_{3} \mathrm{~N}_{4}$ for enhanced photocatalytic performance. Appl. Catal. B Environ. 2019, 247, 24-48. [CrossRef]

33. Yang, Y.; Mao, B.; Gong, G.; Li, D.; Liu, Y.; Cao, W. In-situ growth of Zn-AgIn $\mathrm{S}_{8}$ quantum dots on g-C $\mathrm{C}_{4} \mathrm{~N}_{4}$ towards $0 \mathrm{D} / 2 \mathrm{D}$ heterostructured photocatalysts with enhanced hydrogen production. Int. J. Hydrogen Energy 2019, 44, 15882-15891. [CrossRef]

34. Zeng, Y.; Li, H.; Luo, J. Sea-urchin-structure g- $\mathrm{C}_{3} \mathrm{~N}_{4}$ with narrow bandgap $(\sim 2.0 \mathrm{eV})$ for efficient overall water splitting under visible light irradiation. Appl. Catal. B Environ. 2019, 249, 275-281. [CrossRef]

35. Cerdana, K.; Ouyang, W.; Colmenares, J.C.; Luque, R.; Balu, A.M. Facile mechanochemical modification of g- $\mathrm{C}_{3} \mathrm{~N}_{4}$ for selective photo-oxidation of benzyl alcohol. Chem. Eng. Sci. 2019, 194, 78-84. [CrossRef]

36. Gu, Z.; Zhang, B.; Asakura, Y.; Tsukuda, S.; Yin, S. Alkali-assisted hydrothermal preparation of g- $\mathrm{C}_{3} \mathrm{~N}_{4} / \mathrm{rGO}$ nanocomposites with highly enhanced photocatalytic nox removal activity. Appl. Surf. Sci. 2020, 521, 146213. [CrossRef]

37. Zhang, Q.; Chen, P.; Chen, L.; Wu, M.; He, Y. Facile fabrication of novel $\mathrm{Ag}_{2} \mathrm{~S} / \mathrm{K}-\mathrm{g}-\mathrm{C}_{3} \mathrm{~N}_{4}$ composite and its enhanced performance in photocatalytic $\mathrm{H}_{2}$ evolution. J. Colloids Interfaces Sci. 2020, 568, 117-129. [CrossRef] [PubMed]

38. Li, J.; Yu, X.; Zhu, Y.; Fu, X.; Zhang, Y. 3D-2D-3D BiOI/porous g- $\mathrm{C}_{3} \mathrm{~N}_{4}$ /graphene hydrogel composite photocatalyst with synergy of adsorption-photocatalysis in static and flow systems. J. Alloys Compd. 2020, 850, 156778. [CrossRef] 
39. Arrieta, A.B.; Díaz-Rodríguez, N.; Ser, J.D. Explainable Artificial Intelligence (XAI): Concepts, Taxonomies, Opportunities and Challenges toward Responsible AI. Inf. Fusion 2019, 58, 82-115. [CrossRef]

40. Wang, P. On defining artificial intelligence. J. Artif. Gen. Intell. 2019, 10, 1-37. [CrossRef]

41. Zhu, H. Big data and artificial intelligence modeling for drug discovery. Annu. Rev. Pharmacol. 2020, 60, 573-589. [CrossRef]

42. Jin, X.; Liu, C.; Xu, T.; Su, L.; Zhang, X. Artificial intelligence biosensors: Challenges and prospects. Biosens. Bioelectron. 2020, 165, 112412. [CrossRef]

43. Palkovits, R.; Palkovits, S. Using artificial intelligence to forecast water oxidation catalysts. ACS Catal. 2019, 9, 8383-8387. [CrossRef]

44. Tabatabai-Yazdi, F.S.; Pirbazari, A.E.; Khalilsaraei, F.E.; Kolur, N.A.; Gilani, N. Photocatalytic Treatment of Tetracycline Antibiotic Wastewater by Silver $/ \mathrm{TiO}_{2}$ nanosheets/Reduced Graphene Oxide and Artificial Neural Network Modeling. Water Environ. Res. 2019, 92, 662-676. [CrossRef] [PubMed]

45. Lin, S.; Huang, H.; Ma, T.; Zhang, Y. Photocatalytic Oxygen Evolution from Water Splitting. Adv. Sci. 2020, 8, 2002458. [CrossRef] [PubMed]

46. Wang, W.; Li, G.; Xia, D.; An, T.; Zhao, H.; Wong, P.K. Photocatalytic nanomaterials for solar-driven bacterial inactivation: Recent progress and challenges. Environ. Sci. Nano 2017, 4, 782-799. [CrossRef]

47. Chen, J.; Mao, Z.; Zhang, L.; Wang, D.; Xu, R.; Bie, L.; Fahlman, B.D. Nitrogen DeficientGraphitic Carbon Nitride with Enhanced Performance for Lithium Ion BatteryAnodes. ACS Nano 2017, 11, 12650-12657. [CrossRef]

48. Li, J.; Wu, D.; Iocozzia, J. Achieving efficientincorporation of $\pi$-electrons into graphitic carbon nitride for markedlyimproved hydrogen generation. Angew. Chem. 2019, 58, 1985-1989. [CrossRef]

49. Zhang, G.; Lan, Z.A.; Wang, X. Surface engineering of graphitic carbon nitride polymers with cocatalysts for photocatalytic overall water splitting. Chem. Sci. 2017, 8, 5261-5274. [CrossRef]

50. Kroke, E.; Sehwarz, M.; Horath-Bordon, E.; Kroll, P.; Noll, B.; Norman, A.D. Tri-s-triazine derivatives. Part I. From trichloro-tri-striazine to graphitic $\mathrm{C}_{3} \mathrm{~N}_{4}$ structures. New J. Chem. 2002, 26, 508-512. [CrossRef]

51. Zhao, X.; You, Y.; Huang, S.; Wu, Y.; Zhang, Z. Z-scheme photocatalytic production of hydrogen peroxide over $\mathrm{Bi}_{4} \mathrm{O}_{5} \mathrm{Br}_{2} / \mathrm{g}_{-} \mathrm{C}_{3} \mathrm{~N}_{4}$ heterostructure under visible light. Appl. Catal. B Environ. 2020, 278, 119251. [CrossRef]

52. Pham, T.T.; Shin, E.W. Influence of $\mathrm{g}-\mathrm{C}_{3} \mathrm{~N}_{4}$ Precursors in $\mathrm{g}-\mathrm{C}_{3} \mathrm{~N}_{4} / \mathrm{NiTiO}_{3}$ Composites on Photocatalytic Behavior and the Interconnection between $\mathrm{g}-\mathrm{C}_{3} \mathrm{~N}_{4}$ and $\mathrm{NiTiO}_{3}$. Langmuir 2018, 34, 13144-13154. [CrossRef] [PubMed]

53. Yang, Y.; Geng, L.; Guo, Y.; Meng, J.; Guo, Y. Easy dispersion and excellent visible-light photocatalytic activity of the ultrathin urea-derived g- $\mathrm{C}_{3} \mathrm{~N}_{4}$ nanosheets. Appl. Surf. Sci. 2017, 425, 535-546. [CrossRef]

54. Wang, H.; Sun, Z.; Li, Q.; Tang, Q.; Wu, Z. Surprisingly advanced $\mathrm{CO}_{2}$ photocatalytic conversion over thiourea derived g- $\mathrm{C}_{3} \mathrm{~N}_{4}$ with water vapor while introducing 200-420 nm uv light. J. $\mathrm{CO}_{2}$ Util. 2016, 14, 143-151. [CrossRef]

55. Guo, X.; Duan, J.; Li, C.; Zhang, Z.; Wang, W. Fabrication of $\mathrm{g}-\mathrm{C}_{3} \mathrm{~N}_{4} / \mathrm{TiO}_{2}$ photocatalysts with a special bilayer structure for visible light photocatalytic application. Colloids Surf. A 2020, 599, 124931. [CrossRef]

56. Wang, S.; Lou, D.; Wang, Z.; Yu, N.; Zhang, L. Synthesis of ultrathin g- $\mathrm{C}_{3} \mathrm{~N}_{4}$ /graphene nanocomposites with excellent visible-light photocatalytic performances. Funct. Mater. Lett. 2018, 12, 1950025. [CrossRef]

57. Pati, S.; Acharya, R. An overview on $\mathrm{g}_{-} \mathrm{C}_{3} \mathrm{~N}_{4}$ as a robust photocatalyst towards the sustainable generation of $\mathrm{H}_{2}$ energy. Mater. Today 2021, 35, 175-178.

58. Yda, B.; Ming, Y.; Xla, B.; Cza, B.; Bo, P.; Hui, C. In-situ grown of g- $\mathrm{C}_{3} \mathrm{~N}_{4} / \mathrm{Ti}_{3} \mathrm{C}_{2} / \mathrm{TiO}_{2}$ nanotube arrays on Ti meshes for efficient degradation of organic pollutants under visible light irradiation. Colloids Surf. A 2020, 594, 124511.

59. Lin, Z.; Lin, L.; Wang, X. Thermal nitridation of triazine motifs to heptazine-based carbon nitride frameworks for use in visible light photocatalysis. Chin. J. Catal. 2015, 36, 2089-2094. [CrossRef]

60. Cui, Y.; Ding, Z.; Liu, P.; Antonietti, M.; Fua, X.; Wang, X. Metal-free activation of $\mathrm{H}_{2} \mathrm{O}_{2}$ by g- $\mathrm{C}_{3} \mathrm{~N}_{4}$ under visible light irradiation for the degradation of organic pollutants. Phys. Chem. Chem. Phys. 2012, 14, 1455-1462. [CrossRef]

61. Zhang, W.D.; Su, F.; Xun, C.Q.; Yu, Y.X. Carbon self-doping induced activation of n- $\pi^{*}$ electronic transitions of g- $\mathrm{C}_{3} \mathrm{~N}_{4}$ nanosheets for efficient photocatalytic $\mathrm{H}_{2}$ evolution. ChemCatChem 2016, 8, 3527-3535.

62. Wu, X.; Wang, X.; Wang, F.; Yu, H. Soluble g- $\mathrm{C}_{3} \mathrm{~N}_{4}$ nanosheets: Facile synthesis and application in photocatalytic hydrogen evolution. Appl. Catal. B Environ. 2019, 247, 70-77. [CrossRef]

63. Yang, Z.; Xing, Z.; Feng, Q.; Jiang, H.; Zhang, J.; Xiao, Y.; Li, Z.; Chen, P.; Zhou, W. Sandwich-like mesoporous graphite-like carbon nitride (Meso-g- $\mathrm{C}_{3} \mathrm{~N}_{4}$ )/WP/Meso-g- $\mathrm{C}_{3} \mathrm{~N}_{4}$ laminated heterojunctions solar-driven photocatalysts. J. Colloid Interfaces Sci. 2020, 568, 255-263. [CrossRef]

64. $\mathrm{Xu}$, J.; Li, Y.; Zhou, X. Graphitic $\mathrm{C}_{3} \mathrm{~N}_{4}$-sensitized $\mathrm{TiO}_{2}$ nanotube layers: A visible-light activated efficient metal-free antimicrobial platform. Chem. Eur. J. 2016, 22, 3947-3951. [CrossRef]

65. Maślana, K.; Kaleńczuk, R.J.; Zielińska, B.; Mijowska, E. Synthesis and characterization of nitrogen-doped carbon nanotubes derived from $\mathrm{g}^{-} \mathrm{C}_{3} \mathrm{~N}_{4}$. Materials 2020, 13, 1349. [CrossRef]

66. Li, G.; Lian, Z.; Wang, W.; Zhang, D.; Li, H. Nanotube-confinement induced size-controllable g- $\mathrm{C}_{3} \mathrm{~N}_{4}$ quantum dots modified single-crystalline $\mathrm{TiO}_{2}$ nanotube arrays for stable synergetic photoelectrocatalysis. Nano Energy 2016, 19, 446-454. [CrossRef]

67. Dou, T.; Zang, L.; Zhang, Y.; Sun, Z.; Sun, L.; Wang, C. Hybrid g- $\mathrm{C}_{3} \mathrm{~N}_{4}$ nanosheet/carbon paper membranes for the photocatalytic degradation of methylene blue. Mater. Lett. 2019, 244, 151-154. [CrossRef] 
68. Hu, C.; Chu, Y.C.; Wang, M.S.; Wu, X.H. Rapid synthesis of $\mathrm{g}-\mathrm{C}_{3} \mathrm{~N}_{4}$ spheres using microwave-assisted solvothermal method for enhanced photocatalytic activity. J. Photochem. Photobiol. A 2017, 348, 8-17. [CrossRef]

69. Zhang, Z.; Leinenweber, K.; Bauer, M. High-Pressure Bulk Synthesis of Crystalline $\mathrm{C}_{6} \mathrm{~N}_{9} \mathrm{H}_{3}-\mathrm{HCl}$ : A Novel C $\mathrm{N}_{4}$ Graphitic Derivative. J. Am. Chem. Soc. 2001, 123, 7788-7796. [CrossRef] [PubMed]

70. Liu, G.; Liao, M.; Zhang, Z.; Wang, H.; Feng, Y. Enhanced photodegradation performance of rhodamine $b$ with g- $\mathrm{C}_{3} \mathrm{~N}_{4}$ modified by carbon nanotubes. Sep. Purif. Technol. 2020, 244, 116618. [CrossRef]

71. Du, C.; Lan, X.; An, G.; Li, Q.; Ai, G. Direct Surface Modification of Graphitic $\mathrm{C}_{3} \mathrm{~N}_{4}$ with Porous Organic Polymer and Silver Nanoparticles for Promoting $\mathrm{CO}_{2}$ Conversion. ACS Sustain. Chem. Eng. 2020, 8, 7051-7058. [CrossRef]

72. Chen, X.; Wang, H.; Meng, R.; Chen, M. Porous graphitic carbon nitride synthesized via using carbon nanotube as a novel recyclable hard template for efficient visible light photocatalytic organic pollutant degradation. ChemistrySelect 2019, 4, 6123-6129. [CrossRef]

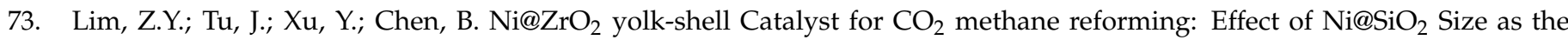
Hard-Template. J. Colloid Interface Sci. 2021, 590, 641-651. [CrossRef]

74. Kadi, M.W.; Mohamed, R.M.; Ismail, A.A.; Bahnemann, D.W. Soft and Hard Templates Assisted Synthesis Mesoporous CuO/g$\mathrm{C}_{3} \mathrm{~N}_{4}$ Heterostructures for Highly Enhanced and Accelerated $\mathrm{Hg}$ (II) Photoreduction under Visible Light. J. Colloid Interface Sci. 2020, 580, 223-233. [CrossRef]

75. Basaleh, A.S. Construction of mesoporous $\mathrm{ZnFe}_{2} \mathrm{O}_{4}-\mathrm{g}-\mathrm{C}_{3} \mathrm{~N}_{4}$ nanocomposites for enhanced photocatalytic degradation of acridine orange dye under visible light illumination adopting soft-and hard-template-assisted routines. J. Mater. Res. Technol. 2021, 11, 1260-1271. [CrossRef]

76. Chen, W.; Liu, M.; Li, X.; Mao, L. Synthesis of $3 \mathrm{~d}$ mesoporous $\mathrm{g}-\mathrm{C}_{3} \mathrm{~N}_{4}$ for efficient overall water splitting under a z-scheme photocatalytic system. Appl. Surf. Sci. 2020, 512, 145782. [CrossRef]

77. Chen, P.; Liu, F.; Ding, H.; Chen, S.; Chen, L.; Li, Y.J. Porous double-shell CdS@ $\mathrm{C}_{3} \mathrm{~N}_{4}$ octahedron derived by in situ supramolecular self-assembly for enhanced photocatalytic activity. Appl. Catal. B Environ. 2019, 252, 33-40. [CrossRef]

78. Luo, L.; Zhang, A.; Janik, M.J.; Li, K.; Song, C.; Guo, X. Facile fabrication of ordered mesoporous graphitic carbon nitride for rhb photocatalytic degradation. Appl. Surf. Sci. 2016, 396, 78-84. [CrossRef]

79. Yu, Y.; Xu, W.; Fang, J.; Chen, D.; Pan, T.; Feng, W.; Liang, Y.; Fang, Z. Soft-template assisted construction of superstructure $\mathrm{TiO}_{2} / \mathrm{SiO}_{2} / \mathrm{g}-\mathrm{C}_{3} \mathrm{~N}_{4}$ hybrid as efficient visible-light photocatalysts to degrade berberine in seawater via an adsorptionphotocatalysis synergy and mechanism insight. Appl. Catal. B Environ. 2020, 268, 118751. [CrossRef]

80. Sun, Z.; Fang, W.; Zhao, L.; Chen, H.; Huang, Z. g- $\mathrm{C}_{3} \mathrm{~N}_{4}$ foam $/ \mathrm{Cu}_{2} \mathrm{O}$ QDs with excellent $\mathrm{CO}_{2}$ adsorption and synergistic catalytic effect for photocatalytic $\mathrm{CO}_{2}$ reduction. Environ. Int. 2019, 130, 104898. [CrossRef]

81. Pan, J.; Dong, Z.; Jiang, Z.; Zhao, C.; Li, C. $\mathrm{MoS}_{2}$ Quantum Dots Modified Black Ti ${ }^{3+}-\mathrm{TiO}_{2} /$ g-C $3 \mathrm{~N}_{4}$ Hollow Nanosphere Heterojunction toward Photocatalytic Hydrogen Production Enhancement. Sol. RRL 2019, 3, 1900337. [CrossRef]

82. Zhou, D.; Qiu, Q. Study on the effect of co doping concentration on optical properties of g- $\mathrm{C}_{3} \mathrm{~N}_{4}$. Chem. Phys. Lett. 2019, 728, 70-73. [CrossRef]

83. Miao, W.; Liu, Y.; Chen, X.; Zhao, Y.; Mao, S. Tuning layered Fe-doped g- $\mathrm{C}_{3} \mathrm{~N}_{4}$ structure through pyrolysis for enhanced fenton and photo-fenton activities. Carbon 2019, 159, 461-470. [CrossRef]

84. Vig, A.S.; Rani, N.; Gupta, A.; Pandey, O.P. Influence of Ca-doped $\mathrm{NaNbO}_{3}$ and its heterojunction with g- $\mathrm{C}_{3} \mathrm{~N}_{4}$ on the photoredox performance. Sol. Energy 2019, 185, 469-479.

85. Zhang, M.; Yang, L.; Wang, Y.; Li, L.; Chen, S. High yield synthesis of homogeneous boron doping $\mathrm{C}_{3} \mathrm{~N}_{4}$ nanocrystals with enhanced photocatalytic property. Appl. Surf. Sci. 2019, 489, 631-638. [CrossRef]

86. Huang, Y.; Li, D.; Fang, Z.; Chen, R.; Luo, B.; Shi, W. Controlling carbon self-doping site of g- $\mathrm{C}_{3} \mathrm{~N}_{4}$ for highly enhanced visible-light-driven hydrogen evolution. Appl. Catal. B Environ. 2019, 254, 128-134. [CrossRef]

87. Zhou, Y.; Lv, W.; Zhu, B.; Tong, F.; Pan, J.; Bai, J. Template-free one-step synthesis of g- $\mathrm{C}_{3} \mathrm{~N}_{4}$ nanosheets with simultaneous porous network and S-doping for remarkable visible-light-driven hydrogen evolution. ACS Sustain. Chem. Eng. 2019, 7, 5801-5807. [CrossRef]

88. Liu, G.; Dong, G.; Zeng, Y.; Wang, C. The photocatalytic performance and active sites of g- $\mathrm{C}_{3} \mathrm{~N}_{4}$ effected by the coordination doping of Fe(III). Chin. J. Catal. 2020, 41, 1564-1572. [CrossRef]

89. Liu, H.; Liang, J.; Fu, S.; Li, L.; Zhou, J. N doped carbon quantum dots modified defect-rich g- $\mathrm{C}_{3} \mathrm{~N}_{4}$ for enhanced photocatalytic combined pollutions degradation and hydrogen evolution. Colloids Surf. A 2020, 591, 124552. [CrossRef]

90. Li, Y.; Fang, Y.; Cao, Z.; Li, N.; Chen, D.; Xu, Q. Construction of g- $\mathrm{C}_{3} \mathrm{~N}_{4} /$ PDI@MOF heterojunctions for the highly efficient visible light-driven degradation of pharmaceutical and phenolic micropollutants. Appl. Catal. B Environ. 2019, 250, 150-162. [CrossRef]

91. Xu, Q.; Zhu, B.; Bei, C.; Yu, J.; Ho, W. Photocatalytic $\mathrm{H}_{2}$ evolution on graphdiyne/g- $\mathrm{C}_{3} \mathrm{~N}_{4}$ hybrid nanocomposites. Appl. Catal. B Environ. 2019, 255, 117770. [CrossRef]

92. Yuan, N.; Zhang, J.; Zhang, S.; Chen, G.; Chen, S. What is the Transfer Mechanism of Photoexcited Charge Carriers for g$\mathrm{C}_{3} \mathrm{~N}_{4} / \mathrm{TiO}_{2}$ Heterojunction Photocatalysts? Verification of Relative p-n Junction Theory. J. Phys. Chem. C 2020, 124, 8561-8575. [CrossRef]

93. Shi, W.; Liu, C.; Li, M.; Lin, X.; Shi, J. Fabrication of ternary $\mathrm{Ag}_{3} \mathrm{PO}_{4} / \mathrm{Co}_{3}\left(\mathrm{PO}_{4}\right)_{2} / g-\mathrm{C}_{3} \mathrm{~N}_{4}$ heterostructure with following Type II and Z-Scheme dual pathways for enhanced visible-light photocatalytic activity. J. Hazard. Mater. 2019, 389, 121907. [CrossRef] 
94. Jia, J.; Jiang, C.; Zhang, X.; Li, P.; Xiong, J.; Zhang, Z. Urea-modified carbon quantum dots as electron mediator decorated $\mathrm{g}-\mathrm{C}_{3} \mathrm{~N}_{4} / \mathrm{WO}_{3}$ with enhanced visible-light photocatalytic activity and mechanism insight. Appl. Surf. Sci. 2019, 495, 143524. [CrossRef]

95. Chi, S.; Ji, C.; Sun, S.; Hua, J.; Sun, C. Magnetically Separated meso-g- $\mathrm{C}_{3} \mathrm{~N}_{4} / \mathrm{Fe}_{3} \mathrm{O}_{4}$ : Bifuctional Composites for Removal of Arsenite by Simultaneous Visible-Light Catalysis and Adsorption. Ind. Eng. Chem. Res. 2016, 55, 12060-12067. [CrossRef]

96. Habibi-Yangjeh, A.; Mousavi, M. Deposition of $\mathrm{CuWO}_{4}$ nanoparticles over $\mathrm{g}-\mathrm{C}_{3} \mathrm{~N}_{4} / \mathrm{Fe}_{3} \mathrm{O}_{4}$ nanocomposite: Novel magnetic photocatalysts with drastically enhanced performance under visible-light. Adv. Powder Technol. 2018, 29, 1379-1392. [CrossRef]

97. Li, Y.; Li, B.; Zhang, D.; Cheng, L.; Xiang, Q. Crystalline carbon nitride supported copper single atoms for photocatalytic $\mathrm{CO}_{2}$ reduction with nearly $100 \%$ CO selectivity. ACS Nano 2020, 14, 10552-10561. [CrossRef]

98. Chen, X.; Wang, J.; Chai, Y.; Zhang, Z.; Zhu, Y. Efficient Photocatalytic Overall Water Splitting Induced by a Giant Internal Electric Field of g- $\mathrm{C}_{3} \mathrm{~N}_{4} / \mathrm{rGO} / \mathrm{PDIP}$ Z-scheme Heterojunction. Adv. Mater. 2021, 33, 2007479. [CrossRef]

99. Zhu, M.; Zhai, C.; Sun, M.; Hu, Y.; Yan, B.; Du, Y. Ultrathin graphitic $\mathrm{C}_{3} \mathrm{~N}_{4}$ nanosheet as a promising visible-light-activated support for boosting photoelectrocatalytic methanol oxidation. Appl. Catal. B Environ. 2017, 203, 108-115. [CrossRef]

100. Jeong, T.; Piao, H.; Park, S.; Yang, J.H.; Song, Y.J. Atomic and electronic structures of graphene-decorated graphitic carbon nitride $\left(\mathrm{g}-\mathrm{C}_{3} \mathrm{~N}_{4}\right)$ as a metal-free photocatalyst under visible-light. Appl. Catal. B Environ. 2019, 256, 117850. [CrossRef]

101. Song, Y.; Tian, J.; Gao, S.; Shao, P.; Qi, J.; Cui, F. Photodegradation of sulfonamides by g- $\mathrm{C}_{3} \mathrm{~N}_{4}$ under visible light irradiation: Effectiveness, mechanism and pathways. Appl. Catal. B Environ. 2017, 210, 88-96. [CrossRef]

102. Liu, L.; Qi, Y.; Lu, J.; Lin, S.; An, W.; Liang, Y.; Cui, W. A stable $\mathrm{Ag}_{3} \mathrm{PO}_{4} @ g-\mathrm{C}_{3} \mathrm{~N}_{4}$ hybrid core@shell composite with enhanced visible light photocatalytic degradation. Appl. Catal. B Environ. 2016, 183, 133-141. [CrossRef]

103. Yan, J.; Song, Z.; Wang, X.; Xu, Y.; Pu, W.; Ji, H.; Xu, H.; Yuan, S.; Li, H. Construction of $3 d$ hierarchical GO/MoS $/$ g-C $_{3} \mathrm{~N}_{4}$ ternary nanocomposites with enhanced visible-light photocatalytic degradation performance. ChemistrySelect 2019, 4, 7123-7133. [CrossRef]

104. Lan, Z.A.; Zhang, G.; Wang, X. A facile synthesis of Br-modified g- $\mathrm{C}_{3} \mathrm{~N}_{4}$ semiconductors for photoredox water splitting. Appl. Catal. B Environ. 2016, 192, 116-125. [CrossRef]

105. Chidhambaram, N.; Ravichandran, K. Single step transformation of urea into metal-free g- $\mathrm{C}_{3} \mathrm{~N}_{4}$ nanoflakes for visible light photocatalytic applications. Mater. Lett. 2017, 207, 44-48. [CrossRef]

106. Li, G.; Wang, B.; Zhang, J.; Wang, R.; Liu, H. Rational construction of a direct z-scheme g- $\mathrm{C}_{3} \mathrm{~N}_{4} / \mathrm{CdS}$ photocatalyst with enhanced visible light photocatalytic activity and degradation of erythromycin and tetracycline. Appl. Surf. Sci. 2019, 478, 1056-1064. [CrossRef]

107. Zhou, Y.; Ye, X.; Lin, D. One-pot synthesis of non-noble metal $\mathrm{WS}_{2} / g-\mathrm{C}_{3} \mathrm{~N}_{4}$ photocatalysts with enhanced photocatalytic hydrogen production. Int. J. Hydrogen Energy 2019, 44, 14927-14937. [CrossRef]

108. Duan, Y. Facile preparation of $\mathrm{CuO} / \mathrm{g}-\mathrm{C}_{3} \mathrm{~N}_{4}$ with enhanced photocatalytic degradation of salicylic acid. Mater. Res. Bull. 2018, 105, 68-74. [CrossRef]

109. Ma, R.; Dong, L.; Li, B.; Su, T.; Luo, X.; Qin, Z.; Ji, H. g- $\mathrm{C}_{3} \mathrm{~N}_{4} / \mathrm{BiYO}_{3}$ Composite for Photocatalytic Hydrogen Evolution. ChemistrySelect 2018, 3, 5891-5899. [CrossRef]

110. Wang, Y.; Yang, W.; Chen, X.; Wang, J.; Zhu, Y. Photocatalytic activity enhancement of core-shell structure g- $\mathrm{C}_{3} \mathrm{~N}_{4} @ \mathrm{TiO}_{2}$ via controlled ultrathin g- $\mathrm{C}_{3} \mathrm{~N}_{4}$ layer. Appl. Catal. B Environ. 2018, 220, 337-347. [CrossRef]

111. Gao, S.; Gu, B.; Jiao, X.; Sun, Y.; Zu, X.; Yang, F.; Zhu, W.; Wang, C.; Feng, Z.; Ye, B.; et al. Highly Efficient and Exceptionally Durable $\mathrm{CO}_{2}$ Photoreduction to Methanol over Freestanding Defective Single-Unit-Cell Bismuth Vanadate Layers. J. Am. Chem. Soc. 2017, 139, 3438-3445. [CrossRef] [PubMed]

112. Jiao, X.; Chen, Z.; Li, X.; Sun, Y.; Gao, S.; Yan, W.; Wang, C.; Zhang, Q.; Lin, Y.; Luo, Y.; et al. Defect-Mediated Electron-Hole Separation in One-Unit-Cell $\mathrm{ZnIn}_{2} \mathrm{~S}_{4}$ Layers for Boosted Solar-Driven $\mathrm{CO}_{2}$ Reduction. J. Am. Chem. Soc. 2017, 139, 7586-7594. [CrossRef] [PubMed]

113. Corp, K.L.; Schlenker, C.W. Ultrafast spectroscopy reveals electron-transfer cascade that improves hydrogen evolution with carbon nitride photocatalysts. J. Am. Chem. Soc. 2017, 139, 7904-7912. [CrossRef] [PubMed]

114. Cui, L.; Ding, X.; Wang, Y.; Shi, H.; Huang, L.; Zuo, Y.; Kang, S. Facile preparation of z-scheme $\mathrm{WO}_{3} /$ g- $\mathrm{C}_{3} \mathrm{~N}_{4}$ composite photocatalyst with enhanced photocatalytic performance under visible light. Appl. Surf. Sci. 2017, 391 Pt B, 202-210. [CrossRef]

115. Cui, L.; Song, J.; McGuire, A.F.; Kang, S.; Fang, X.; Wang, J.; Yin, C.; Li, X.; Wang, Y.; Cui, B. Constructing highly uniform onion-ring-like graphitic carbon nitride for efficient visible-light-driven photocatalytic hydrogen evolution. ACS Nano 2018, 12, 5551-5558. [CrossRef]

116. Qu, J.; Du, Y.; Feng, Y.; Wang, J.; He, B.; Du, M.; Liu, Y.; Jiang, N. Visible-light-responsive k-doped g- $\mathrm{C}_{3} \mathrm{~N}_{4} /$ biobr hybrid photocatalyst with highly efficient degradation of rhodamine b and tetracycline. Mater. Sci. Semicond. Process. 2020, 112, 105023. [CrossRef]

117. Leandri, V.; Gardner, J.M.; Jonsson, M. Coumarin as a Quantitative Probe for Hydroxyl Radical Formation in Heterogeneous Photocatalysis. J. Phys. Chem.C 2020, 123, 6667-6674. [CrossRef]

118. Hou, W.; Deng, C.; Xu, H.; Li, D.; Xia, D. N-P BiOCl@g- $\mathrm{C}_{3} \mathrm{~N}_{4}$ Heterostructure with Rich-oxygen Vacancies for Photodegradation of Carbamazepine. ChemistrySelect 2020, 5, 2767-2777. [CrossRef] 
119. Tang, M.; Ao, Y.; Wang, C.; Wang, P. Facile synthesis of dual Z-scheme g- $\mathrm{C}_{3} \mathrm{~N}_{4} / \mathrm{Ag}_{3} \mathrm{PO}_{4} / \mathrm{AgI}$ composite photocatalysts with enhanced performance for the degradation of a typical neonicotinoid pesticide. Appl. Catal. B Environ. 2020, $268,118395$. [CrossRef]

120. Chen, X.; Zhao, X.; Kong, Z.; Wee-Jun, O.; Li, N.; Mater, J. Unravelling the electrochemical mechanisms for nitrogen fixation on single transition metal atoms embedded in defective graphitic carbon nitride. J. Mater. Chem. A 2018, 6, 21941-21948. [CrossRef]

121. Zhang, S.; Liu, Y.; Gu, P.; Ma, R.; Wen, T.; Zhao, G.; Li, L.; Ai, Y.; Hu, C.; Wang, X. Enhanced photodegradation of toxic organic pollutants using dual-oxygen-doped porous $\mathrm{g}-\mathrm{C}_{3} \mathrm{~N}_{4}$ : Mechanism exploration from both experimental and dft studies. Appl. Catal. B Environ. 2019, 248, 1-10. [CrossRef]

122. Wang, Y.; Tian, Y.; Yan, L.; Su, Z. DFT study on sulfur-doped $g-\mathrm{C}_{3} \mathrm{~N}_{4}$ nanosheets as a photocatalyst for $\mathrm{CO}_{2}$ reduction reaction. $J$. Phys. Chem. C 2018, 122, 7712-7719. [CrossRef]

123. Shi, H.; Zhang, C.; Zhouab, C.; Chen, G. Conversion of $\mathrm{CO}_{2}$ into Renewable Fuel over Pt-g- $\mathrm{C}_{3} \mathrm{~N}_{4} / \mathrm{KNbO}_{3}$ composite photocatalyst. RSC Adv. 2015, 5, 93615-93622. [CrossRef]

124. Wang, J.; Li, X.; You, Y.; Yang, X.; Ying, W.; Li, Q. Interfacial coupling induced direct z scheme water splitting in metal-free photocatalyst: $\mathrm{C}_{3} \mathrm{~N} / \mathrm{g}-\mathrm{C}_{3} \mathrm{~N}_{4}$ heterojunctions. Nanotechnology 2018, 29, 365401. [CrossRef] [PubMed]

125. Wang, W.; Zhou, H.; Liu, Y.; Zhang, S.; Zhang, Y.; Wang, G.; Zhang, H.; Zhao, H. Formation of B-N-C Coordination to Stabilize the Exposed Active Nitrogen Atoms in $\mathrm{g}-\mathrm{C}_{3} \mathrm{~N}_{4}$ for Dramatically Enhanced Photocatalytic Ammonia Synthesis Performance. Small 2020, 16, 1906880. [CrossRef]

126. Gao, Q.; Wang, H.L.; Zhang, L.F.; Hu, S.L.; Hu, Z.P. Computational study on the half-metallicity in transition metal-oxideincorporated $2 \mathrm{D} \mathrm{g}-\mathrm{C}_{3} \mathrm{~N}_{4}$ nanosheets. Front. Phys. 2018, 13, 138108. [CrossRef]

127. Chen, Z.; Mitchell, S.; Vorobyeva, E.; Leary, R.; Hauert, R.; Furnival, T.; Ramasse, Q.; Thomas, J.; Midgley, P.; Dontsova, D.; et al. Stabilization of Single Metal Atoms on Graphitic Carbon Nitride. Adv. Funct. Mater. 2017, 27, 1605785. [CrossRef]

128. Sheng, Y.; Wei, Z.; Miao, H.; Yao, W.; Li, H.; Zhu, Y. Enhanced organic pollutant photodegradation via adsorption/photocatalysis synergy using a $3 \mathrm{~d} g-\mathrm{C}_{3} \mathrm{~N}_{4} / \mathrm{TiO}_{2}$ free-separation photocatalyst. Chem. Eng. J. 2019, 370, 287-294. [CrossRef]

129. Dou, M.; Wang, J.; Gao, B.; Xu, C.; Yang, F. Photocatalytic difference of amoxicillin and cefotaxime under visible light by mesoporous $\mathrm{g}_{-} \mathrm{C}_{3} \mathrm{~N}_{4}$ : Mechanism, degradation pathway and dft calculation. Chem. Eng. J. 2020, 383, 123134. [CrossRef]

130. Wang, Y.; Rao, L.; Wang, P.; Shi, Z.; Zhang, L. Photocatalytic activity of $\mathrm{N}-\mathrm{TiO}_{2} / \mathrm{O}$-doped N vacancy g- $\mathrm{C}_{3} \mathrm{~N}_{4}$ and the intermediates toxicity evaluation under tetracycline hydrochloride and $\mathrm{Cr}(\mathrm{VI})$ coexistence environment. Appl. Catal. B Environ. 2020, $262,118308$. [CrossRef]

131. Guo, F.; Li, M.; Ren, H.; Huang, X.; Shu, K.; Shi, W.; Lu, C. Facile bottom-up preparation of Cl-doped porous g- $\mathrm{C}_{3} \mathrm{~N}_{4}$ nanosheets for enhanced photocatalytic degradation of tetracycline under visible light. Sep. Purif. Technol. 2019, 228, 115770. [CrossRef]

132. Li, D.; Huang, J.; Li, R.; Chen, P.; Chen, D.; Cai, M.; Liu, H.; Feng, Y.; Lv, W.; Liu, G. Synthesis of a carbon dots modified $\mathrm{g}-\mathrm{C}_{3} \mathrm{~N}_{4} / \mathrm{SnO}_{2} \mathrm{Z}$-scheme photocatalyst with superior photocatalytic activity for PPCPs degradation under visible light irradiation. J. Hazard. Mater. 2021, 401, 123257. [CrossRef] [PubMed]

133. Xu, T.; Zou, R.; Lei, X.; Qi, X.; Wu, Q.; Yao, W.; Xu, Q. New and stable g- $\mathrm{C}_{3} \mathrm{~N}_{4} /$ HAp composites as highly efficient photocatalysts for tetracycline fast degradation. Appl. Catal. B Environ. 2019, 245, 662-671. [CrossRef]

134. Nie, Y.C.; Yu, F.; Wang, L.C.; Xing, Q.J.; Liu, X.; Pei, Y.; Zou, J.P.; Dai, W.L.; Li, Y.; Suib, S.L. Degradation of Organic Pollutants Coupled with Simultaneous Photocatalytic $\mathrm{H}_{2}$ Evolution over Graphene Quantum Dots/Mn-N-TiO $/$ g- $\mathrm{C}_{3} \mathrm{~N}_{4}$ Composite Catalysts: Performance and Mechanism. Appl. Catal. B Environ. 2018, 227, 312-321. [CrossRef]

135. Yan, J.; Song, Z.; Wang, X.; Xu, Y.; Pu, W.; Xu, H.; Yuan, S.; Li, H. Enhanced photocatalytic activity of ternary $\mathrm{Ag}_{3} \mathrm{PO}_{4} / \mathrm{GO} / \mathrm{g}_{-} \mathrm{C}_{3} \mathrm{~N}_{4}$ photocatalysts for Rhodamine B degradation under visible light radiation. Appl. Surf. Sci. 2019, 466, 70-77. [CrossRef]

136. Huang, J.; Li, D.; Li, R.; Chen, P.; Zhang, Q.; Liu, H.; Lv, W.; Liu, G.; Feng, Y. One-step synthesis of phosphorus/oxygen co-doped g- $\mathrm{C}_{3} \mathrm{~N}_{4}$ / anatase $\mathrm{TiO}_{2} \mathrm{Z}$-scheme photocatalyst for significantly enhanced visible-light photocatalysis degradation of enrofloxacin. J. Hazard. Mater. 2020, 386, 121634. [CrossRef] [PubMed]

137. Guo, F.; Huang, X.; Chen, Z.; Sun, H.; Chen, L. Prominent co-catalytic effect of CoP nanoparticles anchored on high-crystalline g- $\mathrm{C}_{3} \mathrm{~N}_{4}$ nanosheets for enhanced visible-light photocatalytic degradation of tetracycline in wastewater. Chem. Eng. J. 2020, 395, 125118. [CrossRef]

138. Jiang, L.; Yuan, X.; Zeng, G.; Liang, J.; Chen, X.; Yu, H.; Wang, H.; Wu, Z.; Zhang, J.; Xiong, T. In-situ synthesis of direct solid-state dual Z-scheme $\mathrm{WO}_{3} / \mathrm{g}-\mathrm{C}_{3} \mathrm{~N}_{4} / \mathrm{Bi}_{2} \mathrm{O}_{3}$ photocatalyst for the degradation of refractory pollutant. Appl. Catal. B Environ. 2018, 227, 376-385. [CrossRef]

139. Liu, X.; Li, C.; Zhang, Y.; Yu, J.; Yuan, M.; Ma, Y. Simultaneousphotodegradation of multi-herbicides by oxidized carbon nitride: Performanceand practical application. Appl. Catal. B Environ. 2017, 219, 194-199. [CrossRef]

140. Feng, Z.; Zeng, L.; Zhang, Q.; Ge, S.; Zhao, X.; Lin, H.; He, Y. In situ preparation of g- $\mathrm{C}_{3} \mathrm{~N}_{4} / \mathrm{Bi}_{4} \mathrm{O}_{5} \mathrm{I}_{2}$ complex and its elevated photoactivity in Methyl Orange degradation under visible light. J. Environ. Sci. 2020, 87, 149-162. [CrossRef]

141. Ma, R.; Zhang, S.; Li, L.; Gu, P.; Wen, T.; Khan, A.; Li, S.; Li, B.; Wang, S.; Wang, X. Enhanced Visible-Light-Induced Photoactivity of Type-II $\mathrm{CeO}_{2} / \mathrm{g}-\mathrm{C}_{3} \mathrm{~N}_{4}$ Nanosheet towards Organic Pollutants Degradation. ACS Sustain. Chem. Eng. 2019, 7, 9699-9708. [CrossRef]

142. Deng, Y.; Liu, J.; Huang, Y.; Ma, M.; Liu, K.; Dou, X.; Wang, Z.; Qu, S.; Wang, Z. Engineering the photocatalytic behaviors of g- $\mathrm{C}_{3} \mathrm{~N}_{4}$ Based metal-free materials for degradation of a representative antibiotic. Adv. Funct. Mater. 2020, 30, 2002353. [CrossRef] 
143. Li, X.; Wang, B.; Yin, W.; Di, J.; Xi, J.; Zhu, W.; Li, H. Cu ${ }^{2+}$ Modified g- $\mathrm{C}_{3} \mathrm{~N}_{4}$ Photocatalysts for Visible Light Photocatalytic Properties. Acta. Phys. Chim. Sin. 2020, 36, 1902001. [CrossRef]

144. Deng, Y.; Feng, C.; Tang, L.; Zhou, Y.; Chen, Z.; Feng, H.; Wang, J.; Yu, J.; Liu, Y. Ultrathin low dimensional heterostructure composites with superior photocatalytic activity: Insight into the multichannel charge transfer mechanism. Chem. Eng. J. 2020, 393, 124718. [CrossRef]

145. Chu, M.; Hu, K.; Wang, J.; Liu, Y.; Ali, S.; Qin, C.; Jing, L. Synthesis of g- $\mathrm{C}_{3} \mathrm{~N}_{4}$-based photocatalysts with recyclable feature for efficient 2,4-dichlorophenol degradation and mechanisms. Appl. Catal. B Environ. 2019, 243, 57-65. [CrossRef]

146. Kumar, A.; Khan, M.; He, J.; Lo, I.M.C. Visible-light-driven magnetically recyclable terephthalic acid functionalized g- $\mathrm{C}_{3} \mathrm{~N}_{4} / \mathrm{TiO}_{2}$ heterojunction nanophotocatalyst for enhanced degradation of PPCPs. Appl. Catal. B Environ. 2020, 270, 118898. [CrossRef]

147. Fan, M.; Hu, J.; Cao, R.; Xiong, K.; Wei, X. Modeling and prediction of copper removal from aqueous solutions by nZVI/rGO magnetic nanocomposites using ANN-GA and ANN-PSO. Sci. Rep. 2017, 7, 18040. [CrossRef]

148. Wang, X.J.; Zhao, X.Y.; Li, Q.G.; Chan, T.W.; Wu, S.Z. Artificial neural network modeling and mechanism study for relaxation of deformed rubber. Ind. Eng. Chem. Res. 2016, 55, 4059-4070. [CrossRef]

149. Rasoulifard, M.H.; Dorraji, M.S.; Amani-Ghadim, A.R.; Keshavarz-Babaeinezhad, N. Visible-light photocatalytic activity of chitosan/polyaniline/cds nanocomposite: Kinetic studies and artificial neural network modeling. Appl. Catal. A Gen. 2016, 514, 60-70. [CrossRef]

150. Dorraji, M.S.; Amani-Ghadim, A.R.; Rasoulifard, M.H.; Daneshvar, H.; Aghdam, B.S.Z.; Tarighati, A.R.; Hosseini, S.F. Photocatalytic activity of $\mathrm{g}-\mathrm{C}_{3} \mathrm{~N}_{4}$ : An empirical kinetic model, optimization by neuro-genetic approach and identification of intermediates. Chem. Eng. Res. Des. 2017, 127, 113-125. [CrossRef]

151. Gupta, B.; Gupta, A.K.; Tiwary, C.S.; Ghosal, P.S. A multivariate modeling and experimental realization of photocatalytic system of engineered $\mathrm{S}_{-} \mathrm{C}_{3} \mathrm{~N}_{4} / \mathrm{ZnO}$ hybrid for ciprofloxacin removal: Influencing factors and degradation pathways. Environ. Res. 2020, 196, 110390. [CrossRef] [PubMed] 